گز ينش اكوتيڤ هاى بومى گشنيز متحمل به خشكى براساس عملكرد ميوه و صفات مرتبط به كمك شاخص هاى تكىمتيره و جندمتغيره

بيمان عينىزاده '، حميد دهقانى ب*و مصطفى خدادادى"

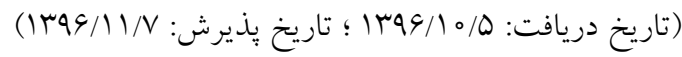

جكيده

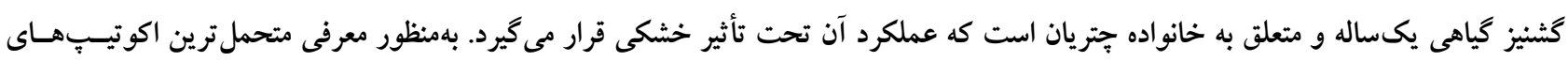

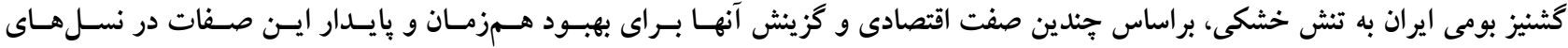

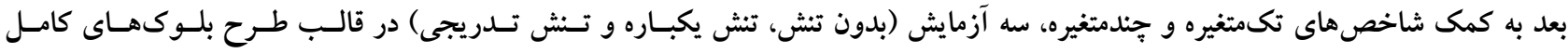

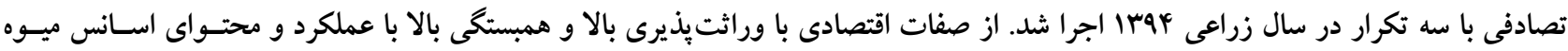

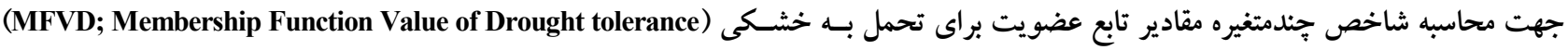

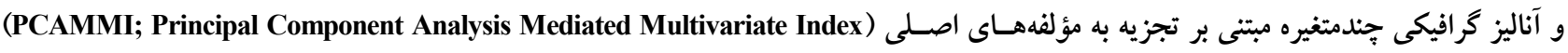

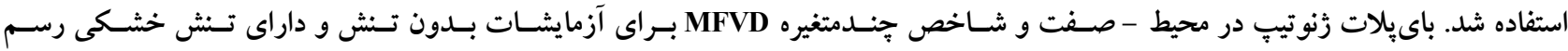

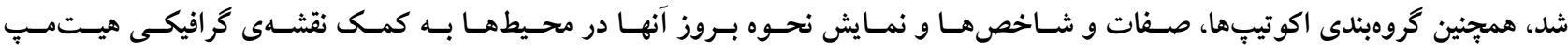

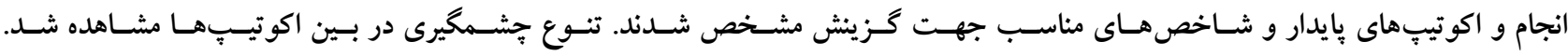

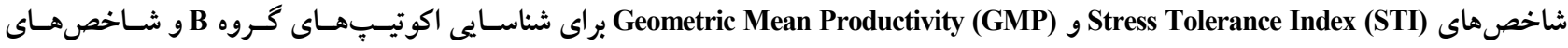

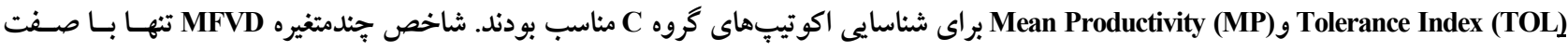

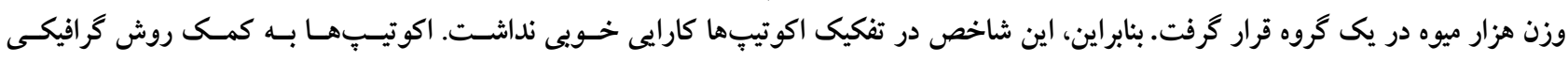
PCAMMI

وازههاى كليدى: باى يلات، ساز گارى به تنش خشكى، شاخصهاى تحمل، شاخص جندمتغيره، نقشه گر افيكى هيتمب

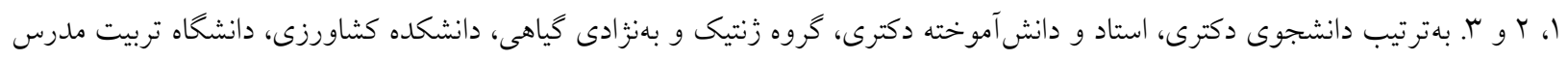

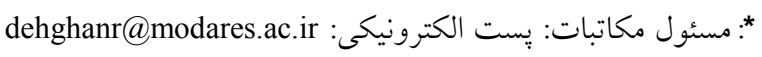




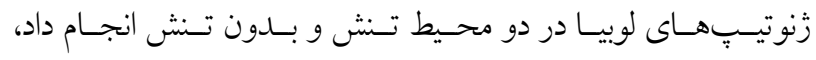

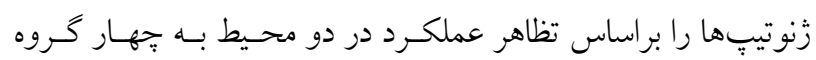

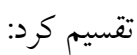
الف-زنوتيبٍهايى كه تظاهر يكسانى در هر دو محسيط تـنش و بدون تنش دارا هستند (كروه A).

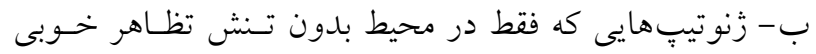

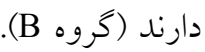
ج- زنوتيبهايى كه فقط در شرايط تنش تظـاهر خـوبى دارنــــ

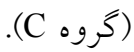
د- زنوتيّهايى كه در هر دو محيط تظاهر خوبى ندارند (كَروه

انتخاب براساس شاخص SSI سبب گز ينش زنوتيِهايى بـا

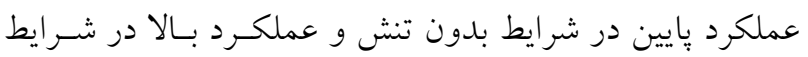

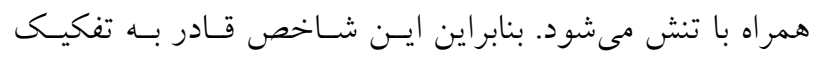

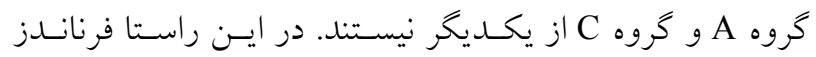

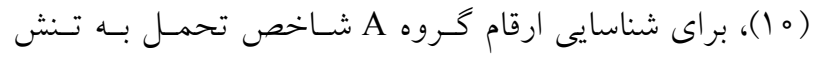

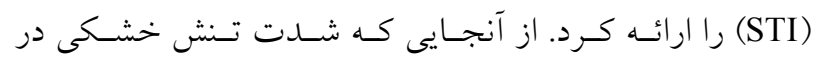
سالهاى مختلـف متفـاوت اسـت، كريستين و همكــاران (Yo)

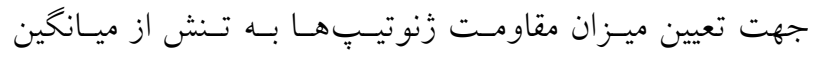
هندسى زنوتيبها (GMP) در دو محيط استفاده كردند. كاهى ممكن است هدف از ززينش، بهبود همزمان جنهـدين

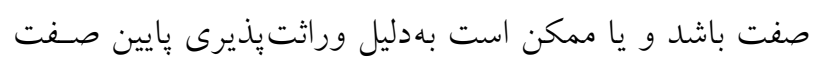

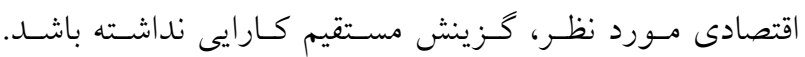

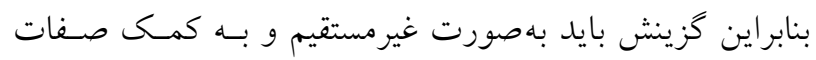

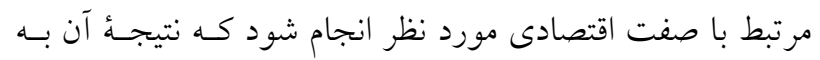

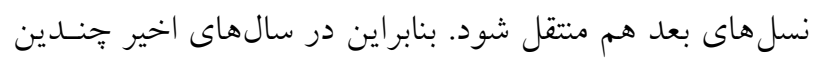

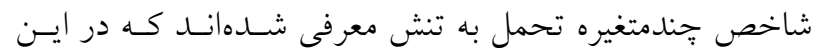
تحقيـق از دو شـاخص MFVD و PCAMMI اسـتفاده شـــ.

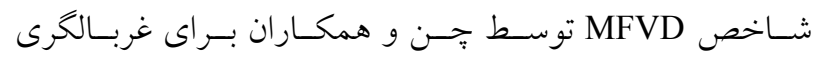
زُنوتيٍٍ هاى متحمل به خشكى در كُندم استفاده شد (r). در اين شاخص عملكرد و صفات مرتبط با عملكرد زنوتيبهـا در هـر دو شرايط تنش و بدون تـنش درنظـر گرفتـه شـده اسـت. ايسن

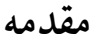

كثنيز گياهى يكساله و متعلق به خانو اده جتريـان (Apiaceae)

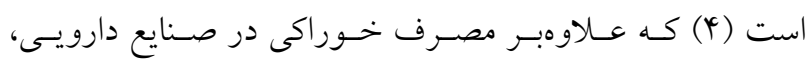

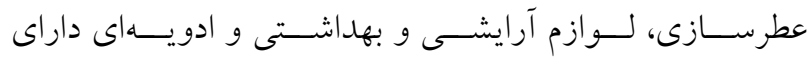

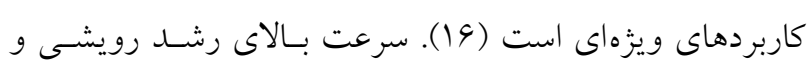

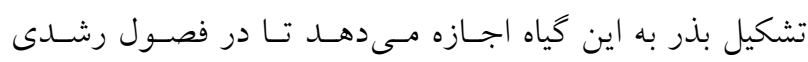

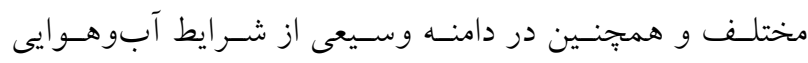

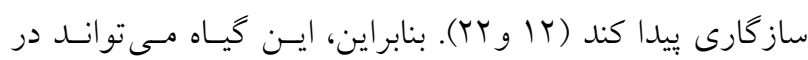
اقليمهاى متفاوت ايران مورد كشت و زرع قرار بخيرد.

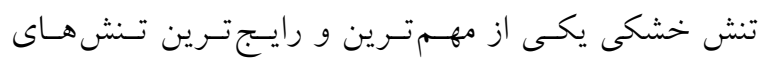

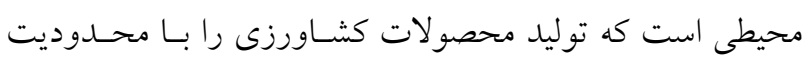

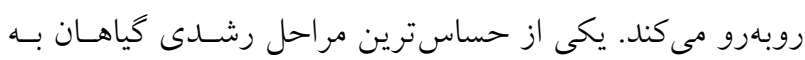

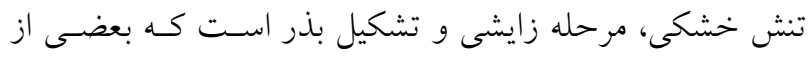

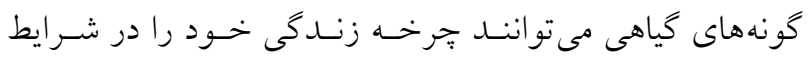

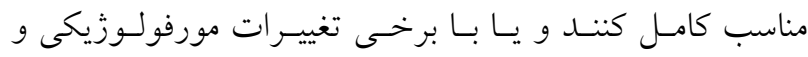

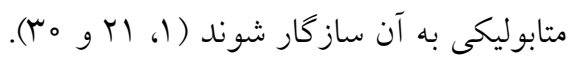

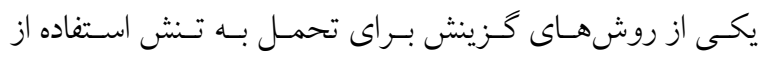
شاخص هاى تكى و جندمتغيره مرتبط با تنش خشكى است. براسـاس رتس

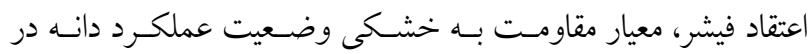

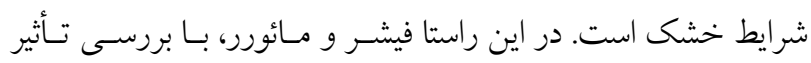

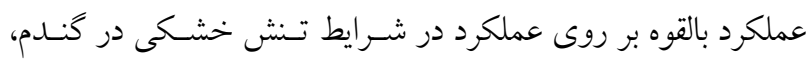

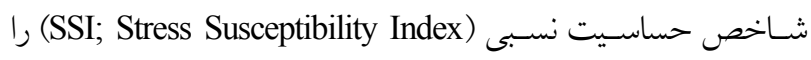
ارائه كردند (11). هر جهه مقدار SSI براى يكى زنوتيبٍ كمتر باشــد، آن

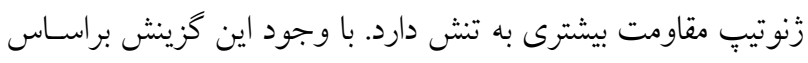

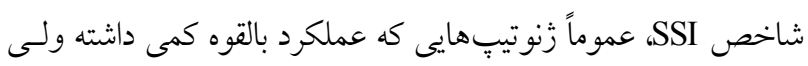

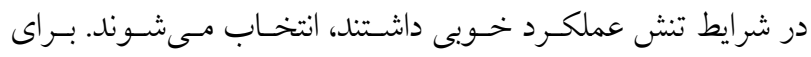

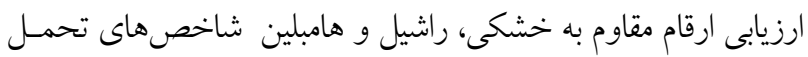

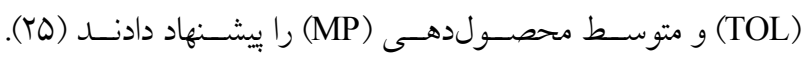

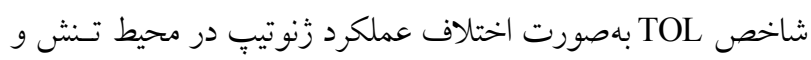

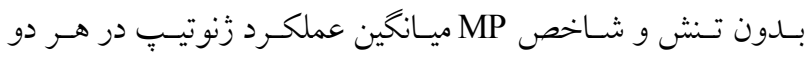
شرايط است و بهدليل تفاوت زياد بـين عملكـرد در دو محسيط داراى

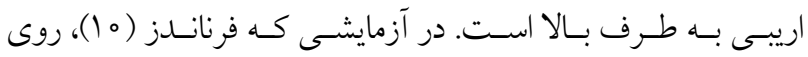


كه در شرايط بدون تنش، آبيارى در زمان رسيدن رطوبت خاك به مها درصد آب در دسترس گياه (PAW; Plant Available Water) انجـام شد. در رزيم آبيارى تنش يكباره، آبيارى تازمان شروع تشكيل ميـوه بهصورت معمولى انجام و سبس تا زمان برداشت ميوه قطـع شـد. در رزيم آبيارى تنش تدريجى، تنش در دو مرحله بدين صـورت اعمـال شد كه تا مرحله ساقهدهى آبيارى بهصورت معمولى و از ساقهدهى تـا لـا شروع تشكيل ميوه در زمان رسيدن رطوبت خاك به هب درصد PAW انجام شد و از آن يُ آبيارى قطع شد. لازم به ذكر است كـه در ايسن

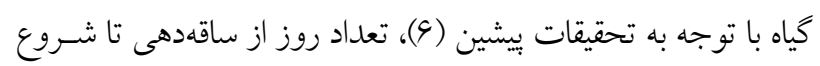
تشكيل ميوه بين ها (زودرستـرين اكوتيـي) تـا ه广 (ديسررستـرين اكوتيٌ) روز و از شروع تشكيل ميوه تا زمان رسيدگى فيزيولوزيكى و برداشت بين ها (زودرسترين اكوتيٍ) تا هY (ديررسترين اكوتيڤ)

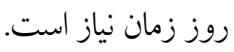

نحوه شناسايى PAW و زمان آبيارى بدين صورت بـود كـه

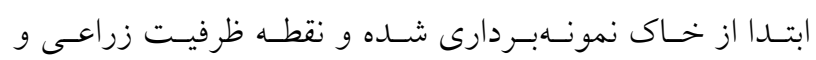
همينطور نقطه يزّمردى دائم مشخص شد و رطوبت بـين ايسن دو نقطه بهعنوان PAW درنظر كرفته شـــ. ســس هــمزمـان بـا انجام عمليات كاشت، يك كرت مـازاد نيـز كشـت شـــ كـه بـه كمكى آن منحنى رطوبتى خـاك رسـم و زمـان تقريبـى رسـيدن رطوبت خاك به مه درصد و مب درصــ PAW مشـخص شـد. سيس در آن زمانها از خاك موجود در عمق ريشـه كـرتهـاى آزمايشى نمونهبردارى و رطوبت محاسبه مى شــ و در صـورت نياز آبيارى صورت مى خرفت.

صفات ارزيابى شده و نحوه اندازهيرى در اين تحقيق صفات اقتصادى با وراثت يذيرى و همبستكى بالا با عملكرد در كشـنيز (و و V) شـامل تعـداد بـرى يايسه، تعـداد شاخه در بوته، تعداد ميوه در بوته، وزن هزار ميوه، عملكرد ميوه در بوته و محتواى اسانس ميوه مورد ارزيابى قرار كرفتند. دليـل

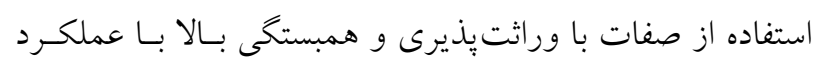

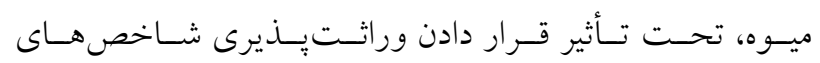

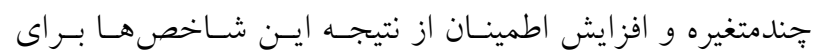

شاخص داراى معايبى نيز هست كـه عبارتنـــ از وراثـتــــيرى يايين، عدم توانايى تفكيك زنوتيبٍهاى گروه A و وجود مشكل همراستايى جندگانه (19). شاخص PCAMMI توسط خدادادى و همكاران ارائه شــ (19) ايـن شـاخص براسـاس تجزيـهـ بــه مؤلفههاى اصلى استوار است كـهـ بـه كمـك نمـودار دو بعـدى

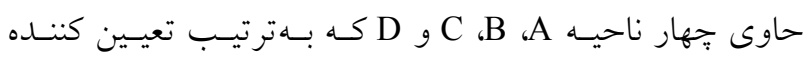

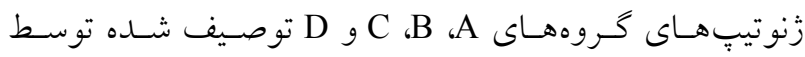
فرناندز هستند، زَنوتيڤها را از هم تفكيك مى كند ( (1).

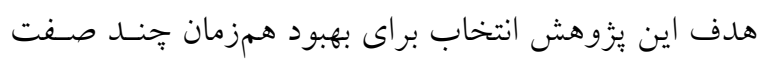
اقتصادى از جمله عملكرد ميوه و ميـزان اسـانس ميـوه در گيـاه

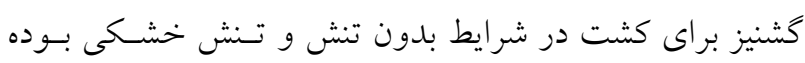

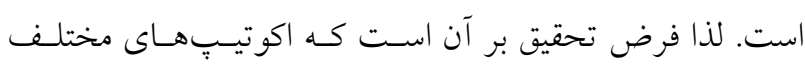

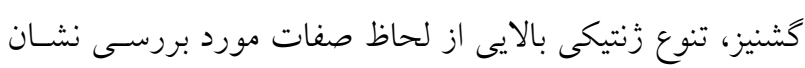

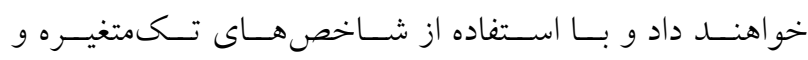
شاخص هاى جنامتغيره تحمل به تسنش خشكى مناسـبـترين

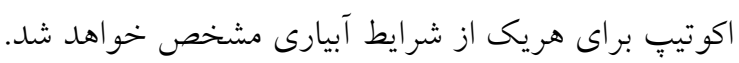

\section{مواد و روشها - ماد}

\section{مواد گياهى و نحوه اعمال تنث} به منظور شناسايى اكوتيبٍ هاى متحمل به تنش خشـكى يكبـاره و

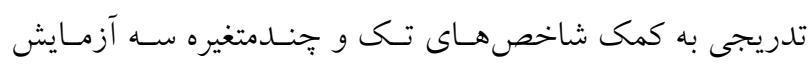
جداگانه (بدون تنش، تـنش يكبـاره و تسنش تـدريجى) در قالـب

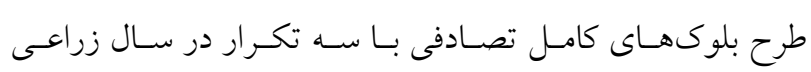


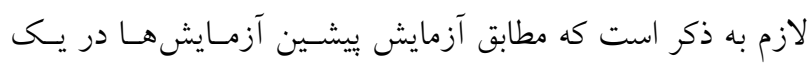
مزرعه تحقيقاتى و در كنار يكديخر اجرا شد (1) (1). در اين تحقيـق

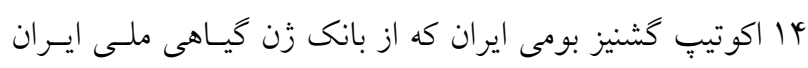
تهيه شده بودند، بههمراه يـك رقـم تجـارى مـورد اسـتفاده قـرار كرفتند. (جدول () يس از عمليات تهيه زمين، كرتهاى آزمايشى به ابعاد Y × Y متـر

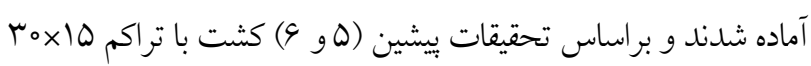
سانتى متر مربع انجام شد. نحوه آبيارى و اعمال تنش بدين صورت بود 


\begin{tabular}{|c|c|c|c|c|c|}
\hline كد & اكوتيب & محل جمع آورى & كد & اكوتيبٍ & محل جمعآورى \\
\hline $\mathrm{P} 1$ & Commercial & كرج & P9 & TN-59-230 & بوشهر \\
\hline $\mathrm{P} 2$ & TN-59-10 & 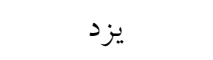 & $\mathrm{P} 10$ & TN-59-306 & آذربايجان غربى \\
\hline P3 & TN-59-36 & فارس & $\mathrm{P} 11$ & TN-59-347 & ل لرستان \\
\hline P4 & TN-59-80 & اصفهان & $\mathrm{P} 12$ & TN-59-353 & مركزى \\
\hline P5 & TN-59-157 & همدان & $\mathrm{P} 13$ & TN-59-357 & كردستان \\
\hline P6 & TN-59-158 & همدان & P14 & TN-59-422 & اصفهان \\
\hline P7 & TN-59-160 & مازندران & P15 & TN-59-450 & فارس \\
\hline P8 & TN-59-164 & مركزى & & & \\
\hline
\end{tabular}

$\operatorname{DSI}=\frac{Y_{p}-Y_{s}}{Y_{p}}$

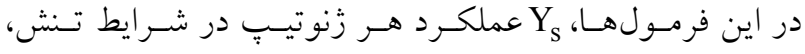

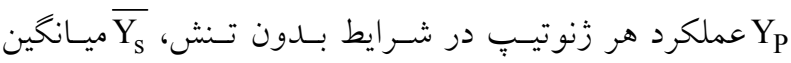

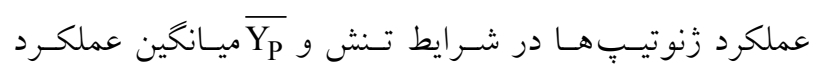
رنوتيِها در شرايط بدون تنش است.

محاسبه شاخص هاى جندمتغيره MFVD و PCAMMI شاخص MFVD به كمك فرمول (V) محاسبه شد: $\mathrm{U}_{\mathrm{i}}=\frac{1}{\mathrm{n}} \sum_{\mathrm{j}=1}^{\mathrm{n}} \mathrm{U}_{\mathrm{ij}}$

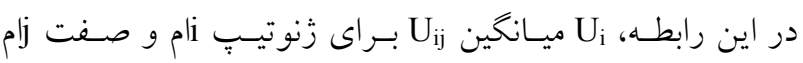

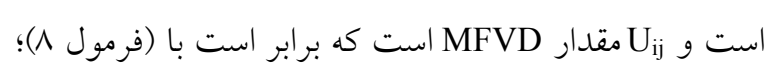

$\mathrm{U}_{\mathrm{ij}}=\frac{\mathrm{DC}_{\mathrm{ij}}-\mathrm{DC}_{\mathrm{jmin}}}{\mathrm{DC}_{\mathrm{jmax}}-\mathrm{DC}_{\mathrm{jmin}}}$

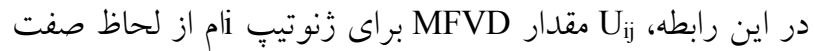

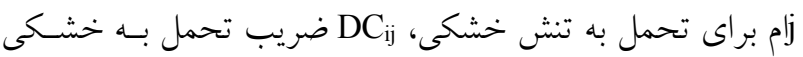
براى زنوتيّ أام و صفت زام، DC و DC تحمل به خشكى حداكثر و حداقل محاسبه شده بـراى صـفت زام

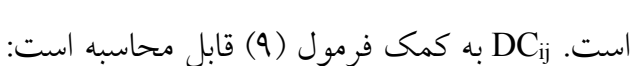
$\mathrm{DC}_{\mathrm{ij}}=\frac{\mathrm{X}_{\mathrm{ijws}}}{\mathrm{X}_{\mathrm{ijww}}}$

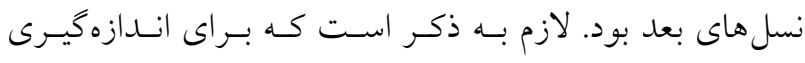

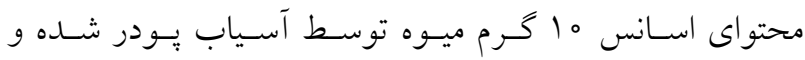

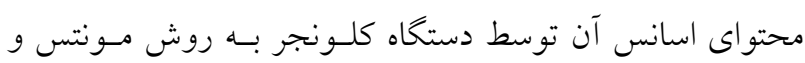

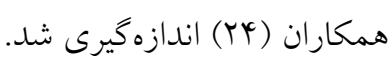

\section{محاسبه شاخصهاى تكمتغيره}

شش شاخص تكمتغيـره شـامل شـاخص حساسـيت بـه تــش

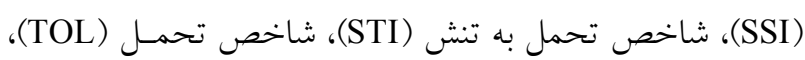

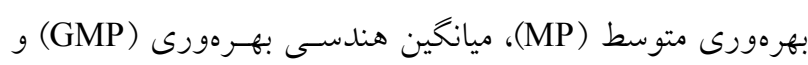

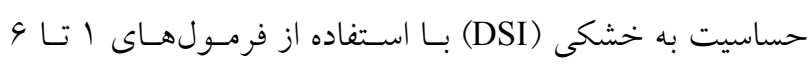

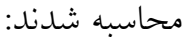

$\mathrm{SSI}=\frac{1-\left(\frac{\mathrm{Y}_{\mathrm{s}}}{\mathrm{Y}_{\mathrm{p}}}\right)}{1-\left(\frac{\overline{\mathrm{Y}_{\mathrm{s}}}}{\overline{\mathrm{Y}_{\mathrm{p}}}}\right)}$

$\mathrm{STI}=\frac{\left(\mathrm{Y}_{\mathrm{p}}\right)\left(\mathrm{Y}_{\mathrm{s}}\right)}{\left(\overline{\mathrm{Y}_{\mathrm{p}}}\right)^{\mathrm{r}}}$

$\mathrm{TOL}=\mathrm{Y}_{\mathrm{p}}-\mathrm{Y}$

$\mathrm{MP}=\frac{\left(\mathrm{Y}_{\mathrm{s}}+\mathrm{Y}_{\mathrm{p}}\right)}{\mathrm{r}}$

$\mathrm{GMP}=\sqrt{\left(\mathrm{Y}_{\mathrm{s}} \cdot \mathrm{Y}_{\mathrm{p}}\right)}$ 


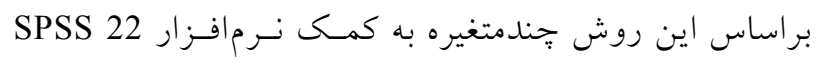

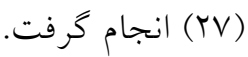

\section{نتايج و بحث تجزيه واريانس}

نتايج تجزيه واريانس مركب تكمتغيره براى همه صـفات نشـان داد

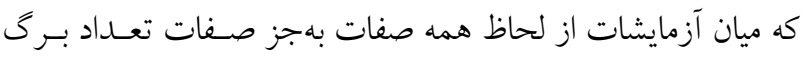

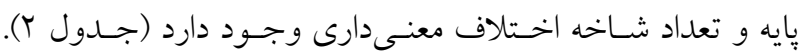

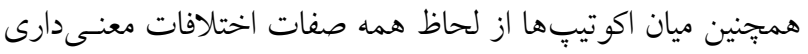

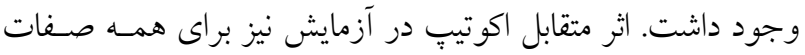
بهجز تعداد برك يايه و وزن هزار ميوه معنىدار بود. بدين معنى كـه.

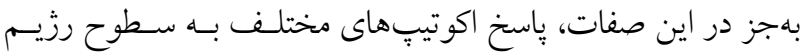

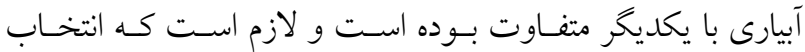
اكوتيب مناسب براساس محيط كشت هدف انجام كيرد.

شاخصهاى تكمتغيره و شاخص جندمتغيره MFVD در اين تحقيق، شش شاخص تكمتغيره كه عموماً جهت بررسى

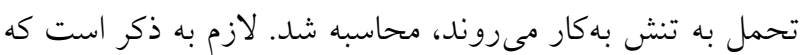

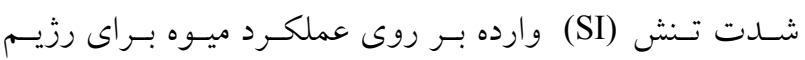

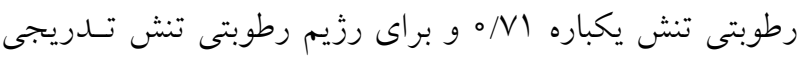

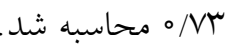
بيشترين مقادير شـاخصهـاى MP ، MOL و و STI در

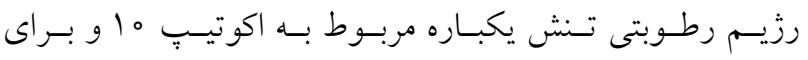

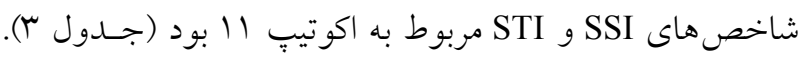

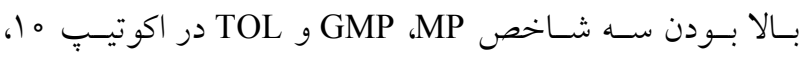
نشاندهنده بالا بودن عملكرد اين اكوتيِ در شر ايط بدون تسنش

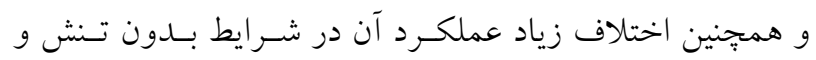
تسنش اسـت. بــالا بـودن شـاخص SSI و پــايين بــودن نسـبى شاخص هاى MP و MMP در اكوتيسٍ ال، نشـان از بـالا بـودن اختلاف عملكرد اين اكوتيب در شرايط بــدون تـنش و تـنش و

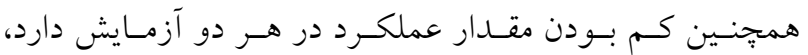
بهلطورى كه اين مو ارد بهخوبى در مقادير عملكرد شـــايط بــدون
در شاخص PCAMMI از ضرايب مؤلفـهـــاى اصـلى براسـاس

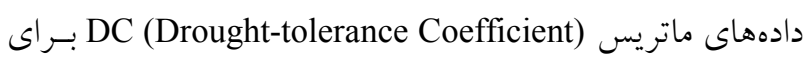
تفكيك زنوتيبٍ هاى كروههاى B و D و از ضرايب مؤلفـهـهـاى

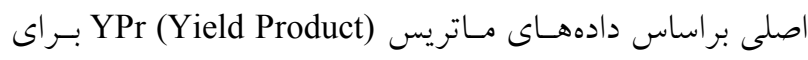
تفكيك زنوتيبهـــاى كـروه A و C اسـتفاده مسى شـود. مر احسل محاسباتى اين روش بهصورت زير انجام مى شود.

$\mathrm{YPr}_{\mathrm{ij}}=\mathrm{Y}_{\mathrm{ijws}} \times \mathrm{Y}_{\mathrm{ijww}}$

در اين رابطه YPrij حاصـل ضـرب عملكـرد زنوتيـٍ أم بـراى

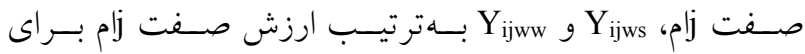
زُنوتيبٍ أlم در شرايط تنش خشكى و بدون تنش است. بـس از

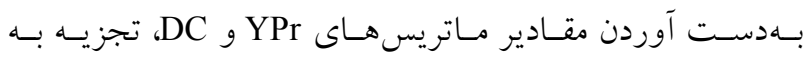
مؤلفههاى اصلى بهطور مجزا بر روى هر كدام از اين ماتريسها

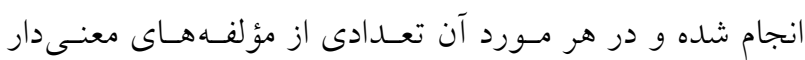
انتخاب و مطابق فرمـولهـاى لآ و كا، محورهــاى نمـودار دو بعدى ذكر شده بهدست مى آيند.

$\mathrm{Y}_{\mathrm{axis}}=\sum_{\mathrm{i}=1}^{\mathrm{n}} \mathrm{PCS}_{\mathrm{YPr}}$

$\mathrm{X}_{\mathrm{axis}}=\sum_{\mathrm{i}=1}^{\mathrm{n}} \mathrm{PCS}_{\mathrm{DC}}$

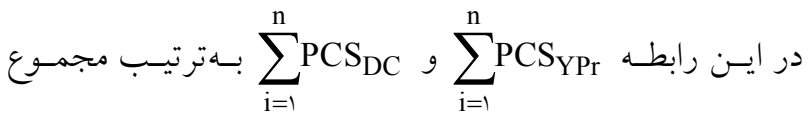

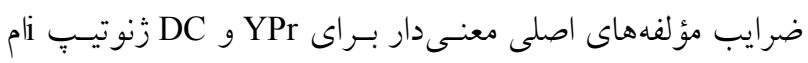

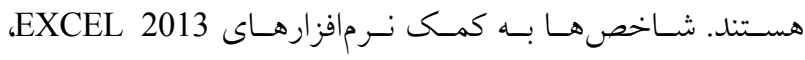
MINITAB 15

آناليز گُر افيكى باى بلات، هيتمب و شاخص PCAMMI

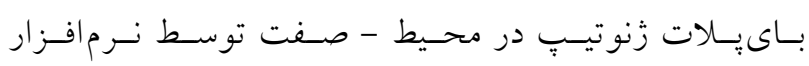
MINITAB ver. 15

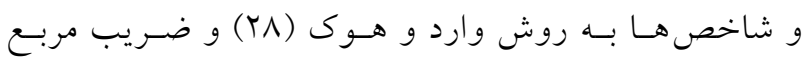

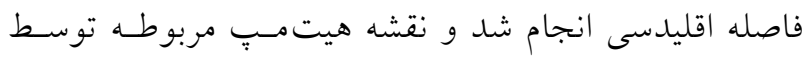

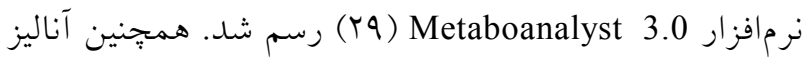

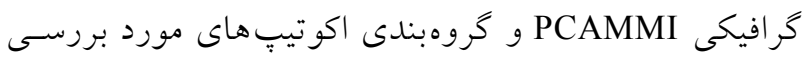


جدول ז. نتايج تجزيه واريانس مركب صفات مورد استفاده براى گزينش به كمك شاخصهاى جندمتغيره در اكوتيبهاى

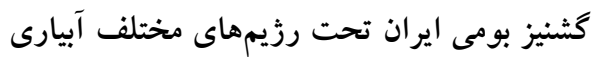

\begin{tabular}{|c|c|c|c|c|c|c|c|}
\hline Es & Yld & FTW & Fno & Bno & BLno & & منابع تغيير \\
\hline$\circ / \circ \wedge^{*}$ & rYVV/I** & $r \mid Y / K^{* *}$ & lorqrAKV/A** & $৭ 9 / 9^{\mathrm{ns}}$ & $r \mathscr{V V} / \mathscr{G}^{\mathrm{ns}}$ & r & رزيم آبيارى \\
\hline ०/०००ץ & $9 / 1$ & $\mu / 。$ & lopgkr/A & $r M / Q$ & $100 / 4$ & 9 & خطاى اصلى \\
\hline $0 / 0010^{* *}$ & $\mathcal{Y} \wedge / \circ^{* *}$ & $1 \Lambda / 0^{* *}$ & $\Delta G \circ Y Y Y / D^{* *}$ & $\mu /^{* *}$ & $q 4 / 1^{* *}$ & 14 & اكوتيبٍ \\
\hline 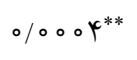 & $\Delta \Lambda / V^{* *}$ & $V / q^{n s}$ & m.rqY/N** & Q/ons & $r T / Y^{\text {ns }}$ & r^ & اكوتيبٍ × رزيم آبيارى \\
\hline O/OO०Y & $r / q$ & $4 / q$ & MTING/9 & $r / l$ & $\Lambda / v$ & $\Lambda F$ & خطاى فرعى \\
\hline
\end{tabular}

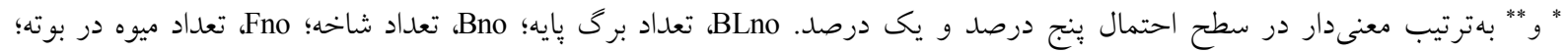
FTW وزن هزار ميوه؛ Yld، عملكرد ميوه؛ HI و Es

جدول س. مقادير شاخصهاى تك و جِندمتغيره اكوتيبها در رزيم رطوبتى تنش يكباره

\begin{tabular}{|c|c|c|c|c|c|c|c|c|c|}
\hline MFVD & DSI & STI & SSI & TOL & GMP & MP & Ys1 & Yn & اكوتيب \\
\hline$\circ / Y V$ & $\circ / N \Delta$ & $\circ / \pi q$ & $1 / 09$ & $19 / 4 V$ & $1 \circ / N{ }^{F}$ & 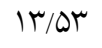 & $\Delta / \mu_{\circ}$ & $T I / N V$ & $\mathrm{P} 1$ \\
\hline$\circ / 4 V$ & $\circ / Y V$ & $0 / 49$ & •/OH & $0 / 09$ & $11 / \mathrm{V}$ & $\mid r / O r$ & $q / Y Y$ & $\mid r / A r$ & $\mathrm{P} 2$ \\
\hline $0 / T_{1}$ & $0 / 91$ & $0 / 40$ & ०/^G & $11 / \mu \pi$ & $\| / \& V$ & $1 Y / A_{0}$ & $V / I r$ & $11 / 49$ & P3 \\
\hline س & O/AY & $0 / Y G$ & $1 / 10$ & $19 / 94$ & N/VG & $|r /| \Lambda$ & $r / V I$ & $r_{0} / 90$ & P4 \\
\hline $0 / 40$ & $0 / 41$ & $\circ / Y I$ & $\circ / \Delta \wedge$ & T/MT & V/ar & $N / Y I$ & $4 / 00$ & $10 / \mu V$ & P5 \\
\hline Tr & $\circ / N^{4}$ & $\circ / \pi$ & $1 / 04$ & $\mid r / q r$ & $10 / 14$ & $1 K / 90$ & $0 / 1 \mu$ & ro/0G & P6 \\
\hline את/。 & ०NG & $0 / Y q$ & $1 / \circ V$ & $\mid k / \mu k$ & $Q / Y T$ & $11 / 9 \Lambda$ & $Y / D 1$ & $1 \wedge / \wedge \Delta$ & P7 \\
\hline$\circ / T \Delta$ & $\circ / 0 \circ$ & $0 / Y G$ & $\circ / V I$ & $9 / 4$ & $\Lambda / \wedge \Delta$ & $q / 41$ & $q / r_{0}$ & $\mid r / g r$ & P8 \\
\hline$\circ / \Lambda \mid$ & $-r / \Delta \circ$ & $0 / 01$ & $-y / q r$ & $-r / A r$ & $\mid / V 1$ & $T / Y Y$ & r/gr & $\circ / \Lambda \circ$ & P9 \\
\hline$\circ / \mu_{0}$ & $\circ / \Lambda \mid$ & $\circ / \Delta \circ$ & $1 / 14$ & Tr/Vo & $1 T / 10$ & $19 / 94$ & $Q / \Upsilon \wedge$ & $r V / q \Lambda$ & P10 \\
\hline OMY & $\circ / 19$ & $0 / 09$ & $1 / T Q$ & IT/KG & $\varphi / \Delta \circ$ & $V / 90$ & $1 / 49$ & $\mid r / \Lambda r$ & P11 \\
\hline$\circ / \Gamma_{0}$ &.$/ 90$ & $\circ / Y I$ & o/9r & $N / 94$ & $V / 99$ & $q / 1 r$ & $4 / 94$ & $14 / 90$ & $\mathrm{P} 12$ \\
\hline$\circ / K V$ & o/AY & $0 / Y G$ & $1 / 19$ & $19 / Y_{0}^{\circ}$ & N/A & $1 \% / 09$ & r/4q & Tr/94 & P13 \\
\hline O/TY & $\circ / \Lambda \Lambda$ & o/YY & $1 / T \Delta$ & $r Y / Y l$ & $N / 41$ & $|y / 0|$ & Y/AI & $r Q / T r$ & P14 \\
\hline $0 / 10$ & $0 / 91$ & $\circ / T V$ & ०/^G & $N / q Y^{4}$ & $Q / \circ T$ & $10 / 0 \mathrm{~V}$ & $0 / 9 \circ$ & $\mid Y / D Y$ & P15 \\
\hline
\end{tabular}


شاخص هاى TOL و SSI و DSI و همجينين يـايين بـودن MP و GMP

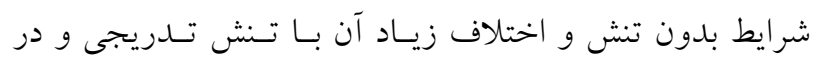
نتيجه حساسيت زياد اين اكوتيبٍ به اين نوع تنش است. در اين آزمـايش نيـز مقـادير شـاخصهــاى TOL و SSI و DSI بــراى

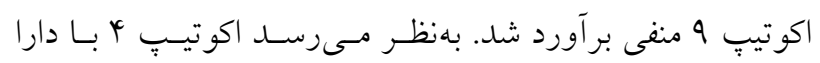
بودن بيشترين عملكرد در شرايط تسنش و حساسـيت كمتـر بـه تنش تدريجى براى كشت در مناطقى كـهـ تسنش خشـكى طـول فصل در آنها وجود دارد، مناسبترين اكوتيبٍ است. اكوتيـيٍ 9 نيز بهدليل سرعت زيـاد آن در تكميـل مراحـل رشــى و عـدم

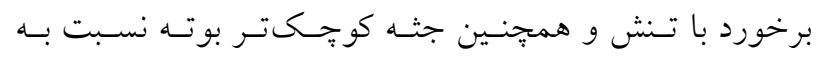
اكوتيٍهاى ديخر، با افزايش تراكم كشت مىتواند در اين مناطق توصيه شود (جدول †). البته بايد به اين نكتهه توجسه شـود كـه افزايش بيش از حد تراكم باعث افزايش سايهانــازى و كـاهش توليد كل و ميوه مىشود. براساس نتايج نشان داده شده در جدولهاى ب و بأو مـوارد ذكـر شــده در مـورد روش تجنـدمتغيره MFVD متحمــل تـرين

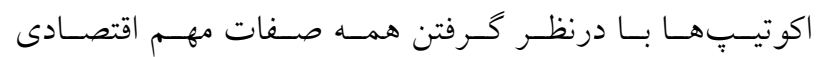

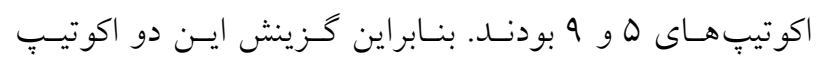
مىتواند در افزايش تحمل كياه گشنيز به خشكى طول فصـل در نسل هاى بعدى تأثير گذار است.

همبستخى بين شاخصها با عملكرد ميوه (جدول ها ) مقادير ضرايب همبستخى بيرسون بين شاخص هـا و

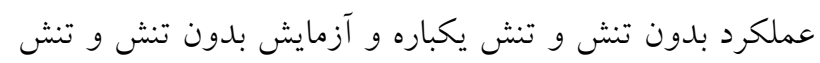
تــريجيى را نشـان مسىدهـد. همـانطوركـه ملاحظـه مسى شـود همبسـتحى دو شـاخص SSI و DSI در هــر دو آزمـايش تسنش برابر يك بود. در مطالعات ديخر نيز همبستخى هاى بـالايى بـين اين دو شاخص گزارش شده است (r و A). در هر دو آزمـايش همبستخى بيشتر شاخص ها با عملكـرد ميـوه در شـرايط بــدون تــش (Y) بيشـتر از عملكــرد در شـرايط تـنش (Y) ) بـود. در تحقيق زينالى و همكاران (ب) بــر روى كيـاه سـويا نيـز نتـايج
تنش (Yp) و عملكرد رزيم رطوبتى تنش يكبـاره (Ys) مشـاهده مىشود (جدول س). اكوتيّ 9 بهدليل نشان دادن عملكرد بيشـتر در شرايط تنش، داراى مقادير منفى بـراى شـاخصهــاى TOL، بود. دو ديل عدم كاهش عملكـــد در ايسن اكوتيـٍ را SSI

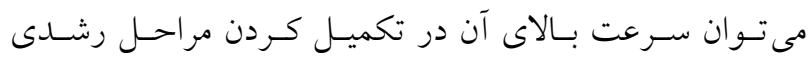
دانست، بهكونهاى كه تا قبل از برخورد با تنش خشكى تشـكيل ميوه كرده و به اصطلاح از خشـكى فـرار مسى كنـد و البتـه ايسن اكوتيبٍ بهدليل نداشتن زمـان كـافى بـــاى رشـــ رويشسى داراى عملكرد يايينى در هر دو شرايط بدون تنش و داراى تـنش بــود.

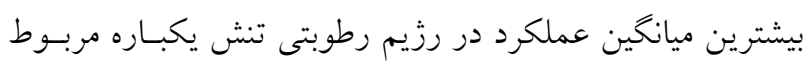

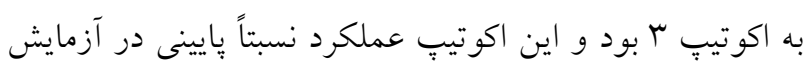
بدون تنش داشت. بنـابراين ميـزان شـاخص TOL نيـز در ايسن

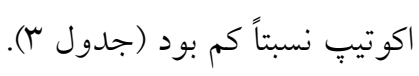

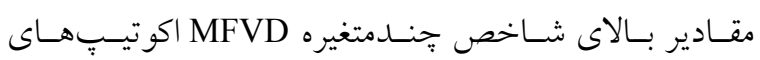

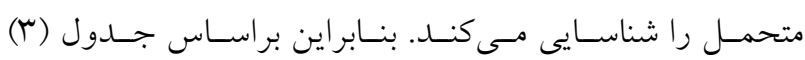
اكوتيڤهاى 9 و r از نظر كليه صفات اقتصادى اندازه گيرى شده

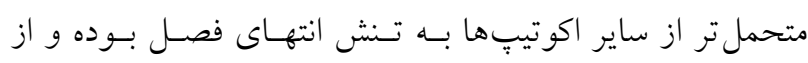

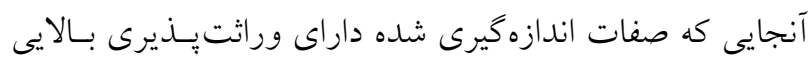
بودند، مىتوان نتيجه كرفت كه احتمالاً اين اكوتيِها مى تواننــ تحمل به تنش را بـه نسـل بعـد منتقـل كنــــ. بنـابراين ايسن دو اكوتيٍِ را مىتوان براى مناطقى با خطر خشـكى انتهـاى فصـل توصيه كرد.

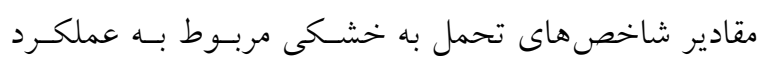
ميوه براى رزيم رطوبتى تنش تدريجى در (جدول †) نشان داده

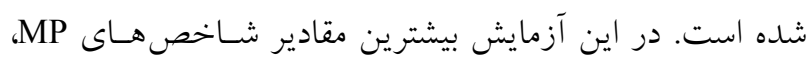
و و STI SSI ، TOL GMP بهترتيب مربوط به اكوتيبٍهاى

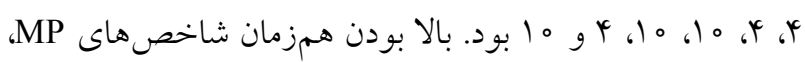
و و و همجينين يايين بـودن نسـبى شـاخص TOL

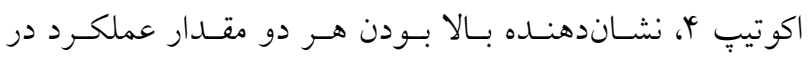
آزمايش هاى بدون تنش و تنش تدريجى بوده و مقاومت نسـبى اين اكوتيب را به تنش تـدريجى نشـان مسى دهـد. همتجنسين در (جدول †) مشاهده مسى شـود كـه بـالا بـودن هــمزمـان مقـادير 
جدول fا. مقادير شاخصهاى تك و جֶندمتغيره اكوتيبها در رزيم رطوبتى تنش تدريجى

\begin{tabular}{|c|c|c|c|c|c|c|c|c|c|}
\hline MFVD & DSI & STI & SSI & TOL & GMP & MP & Ys2 & Yn & اكوتيِ \\
\hline$\circ / \mu_{0}$ & $\circ / v q$ & D/MY & $1 / 09$ & $\mid V / r q$ & 9/V9 & $1 \mathrm{r} / \circ \mathrm{V}$ & $\varphi / \mu \wedge$ & TI/VV & $\mathrm{P} 1$ \\
\hline - $/ \Delta Y$ & $\circ / \mathrm{V} 0$ & O/YY &.$/ 99$ & $10 / 40$ & $1 / \circ 9$ & $9 / 90$ & $\varphi / \mu \wedge$ & IY/Ar & $\mathrm{P} 2$ \\
\hline זسום & $\circ / v q$ & $O / Y^{Y}$ & $1 / \circ \wedge$ & $14 / 94$ & $\Lambda / \Gamma V$ & $11 / 1 r$ & r/A。 & $11 / 4 \varphi$ & P3 \\
\hline $0 / \mu 1$ & $\circ / \mu \wedge$ & $\circ / \wedge 9$ & •/QT & $N / \circ r$ & $19 / 14$ & $19 / 94$ & $|r / 9|$ & $r_{0} / 90$ & P4 \\
\hline $0 / 90$ & $\circ / N$ & $0 / 09$ & $1 / 01$ & $V / 9 V$ & $0 / r q$ & $9 / 0 r$ & YNo & $10 / \mu V$ & P5 \\
\hline$\circ / Y \Lambda$ & $\circ / \wedge Q$ & $\circ / Y_{0}$ & $1 / 19$ & $1 \mathrm{~V} / 0 \mathrm{G}$ & $V / V D$ & $11 / 0 r$ & $\mu / \circ \circ$ & $r_{0 / 0 G}$ & P6 \\
\hline سת/。 & $0 / 99$ & $0 / 49$ &.$/ 90$ & $1 \% / 10$ & $10 / 44$ & $I T / T V$ & $Q / V \circ$ & IN/AD & P7 \\
\hline$\circ / \mu V$ & $0 / 9 \mu$ & $\circ / Y_{0}$ & ०/^צ & N/०。 & $V / 90$ & N/G & $\varphi / q \mu$ & $\mid r / g r$ & P8 \\
\hline $0 / 99$ & $-\Delta / \circ \varphi$ & $0 / 01$ & $-9 / 9 Y$ & $-\psi / \circ \wedge$ & $1 / 91$ & $\Gamma / \wedge Q$ & $r / 19$ & $\circ / \wedge \circ$ & P9 \\
\hline O/T & $0 / 99$ & $\circ / \wedge \wedge$ & $1 / T r$ & $r V / T$ & $r / \wedge q$ & $\mid Y / F T$ & $\circ / \wedge Q$ & $r V / 9 \Lambda$ & $\mathrm{P} 10$ \\
\hline$\circ / \Lambda$ & $0 / 09$ & $\circ / T \Lambda$ & ०/VG & V/VG & $9 / 19$ & $9 / 90$ & $9 / 09$ & $1 \Gamma / \Lambda \mu$ & P11 \\
\hline$\circ / N \Delta$ & $\circ / \Lambda \circ$ & $0 / 1 Y$ & $1 / 09$ & $10 / 94$ & $9 / 0 r$ & $N /{ }^{\mathrm{F}}$ & $r / 9 V$ & $1 \pi / 90$ & P12 \\
\hline $0 / 41$ & $0 / \Lambda 1$ & $0 / M 1$ & $1 / 11$ & $1 N / \Delta D$ & $9 / 90$ & $\| \mu \wedge$ & $4 / 11$ & $r Y / 99$ & P13 \\
\hline $0 / \pi q$ & $\circ / \wedge Q$ & OMT & $1 / 19$ & $r|/ D|$ & $9 / 9 \wedge$ & $\mid \Psi / 4 V$ & $r / V I$ & $T Q / T Y T$ & P14 \\
\hline $0 / r 1$ & 0/gr & $0 / 49$ & ०/^G & $9 / 19$ & $\wedge / \wedge \mathcal{F}$ & $9 / 99$ & $\Delta / \Gamma \wedge$ & $|Y / Q|^{c}$ & P15 \\
\hline
\end{tabular}

جدول ه. ضرايب همبستخى بيرسون بين شاخصها و عملكرد آزمايش بدون تنش و

تنش يكباره (بالاى قطر) و آزمايش بدون تنش و تنش تدريجى (يايين قطر)

\begin{tabular}{|c|c|c|c|c|c|c|c|c|c|}
\hline MFVD & DSI & STI & SSI & TOL & GMP & MP & Ys1 & Yn & \\
\hline$-0 / 9 Y^{*}$ & $\circ / V Y^{* *}$ & $0 / 90^{* *}$ & $\circ / Y^{* * *}$ & $\circ / 99^{* *}$ & $\circ / I^{* *}$ & $0 / 99^{* *}$ & $-0 / \circ V$ & $1 / 00$ & Yn \\
\hline$-0 / 0 Y$ & $0 / 09$ & $\circ / 9 \Lambda^{* *}$ & $0 / 09$ & س & $0 / 9 Y^{*}$ & $0 / Y$ & $1 / 00$ & $-0 / \circ \mathrm{V}$ & Ys2 \\
\hline$-0 / 9 Y^{*}$ & $\circ / V^{* * *}$ & 。/A & $\circ / Y^{* *}$ & $\circ / \wedge \Delta^{* *}$ & $\circ / \wedge V^{* *}$ & $1 / 00$ & $0 / Y q$ & $\circ / 9 r^{* *}$ & MP \\
\hline$-\circ / \Delta V^{*}$ & $0 / 9 \Lambda^{* *}$ & $\circ / 99^{* *}$ & $\circ / 9 \Lambda^{* *}$ &.$/ 01^{*}$ & $1 / 00$ & ०/VG & $\circ / V Q$ &.$/ 0$ & GMP \\
\hline$-\circ / \Delta \wedge^{*}$ & $0 / 9 \wedge^{* *}$ & $0 / 4 y$ & $\circ / 9 \wedge^{* *}$ & $1 / 00$ & $0 / 19$ & $\circ / Y^{4 * *}$ & $-0 / 4 Y$ & ./9r & TOL \\
\hline$-\circ / \Lambda \varphi^{* *}$ & 1 & $\circ /\left.\Delta\right|^{*}$ & $1 / 00$ & $\circ / 9 V^{* *}$ & $0 / 4 q$ & $0 / 9 r^{*}$ & $-0 / 11$ & $\circ / V^{*}$ & SSI \\
\hline$-0 / \mu_{0}$ & $\circ /\left.\Delta\right|^{*}$ & $1 / 00$ & $0 / Y \Lambda$ & $0 / 04$ & $\circ / 90^{* *}$ & $0 / 99^{* *}$ & $\circ / \wedge V^{* *}$ & $\circ / \Lambda$ & STI \\
\hline$-\circ / \Lambda \varphi^{* *}$ & $1 / 00$ & $0 / T V$ & 1 & $\circ / 9 V^{* *}$ & $0 / 4 q$ & $0 / 9 Y^{*}$ & $-0 / 11$ & $\circ / V^{*}$ & DSI \\
\hline $1 / 00$ & $-0 / 90^{*}$ & $-0 / \gamma \wedge$ & $-0 / 90^{*}$ & $-o / V r^{* *}$ & $-0 / \mu q$ & $-\circ / N r^{* * *}$ & $0 / 04$ & $-\circ / V \Lambda^{* *}$ & MFVD \\
\hline
\end{tabular}

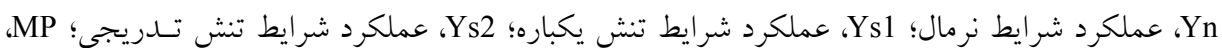

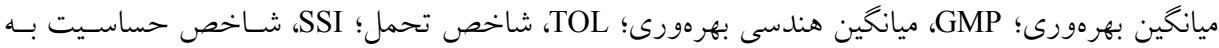

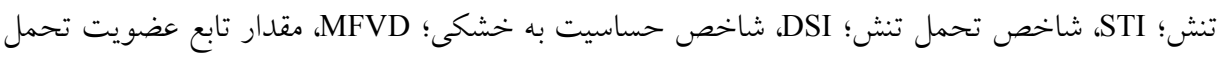


آزمايشات بدون تنش و تسنش يكبـاره در (شـكل () نشـان داده

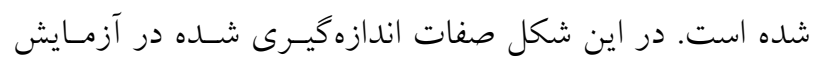

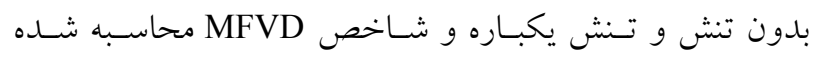

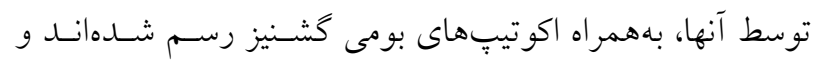

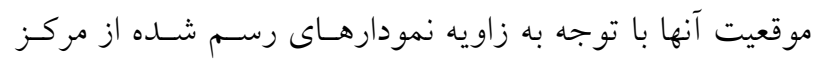
مختصات نسبت به يـكديخــر مشـحص شـــه اسـت. ملاحظـه

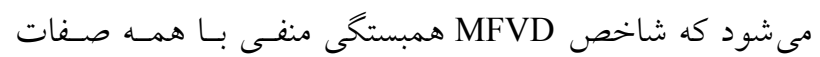

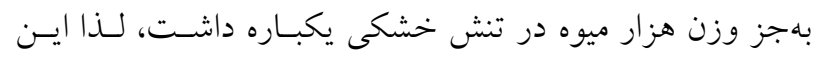

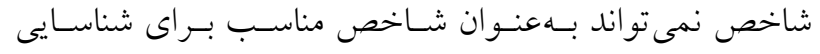

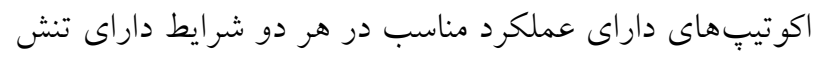

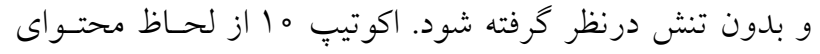
اسانس در هر دو شـرايط عـدم تـنش و تسنش خشكى يكبـاره

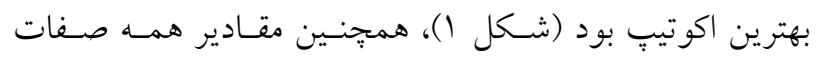

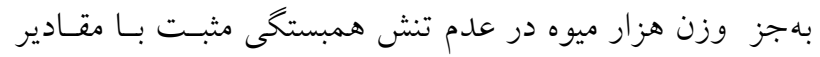

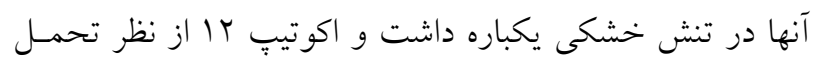
تنش خشكى يكباره و صفات مهم اقتصادى مانند عملكرد ميـوه

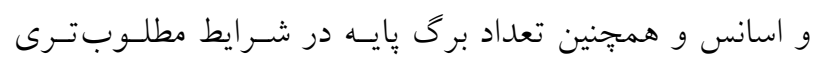
نسبت به ساير اكوتيبٍها قرار داشت.

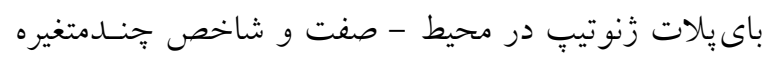

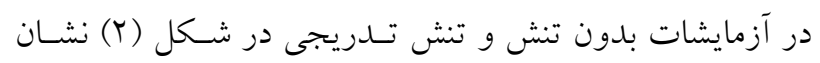

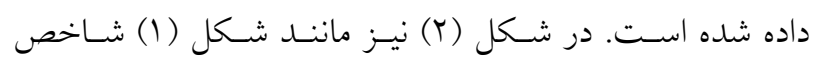
MFVD با اكثر صفات رابطه منفى داشت. همانطور كه ملاحظـه.

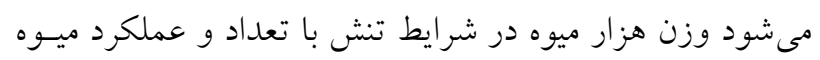

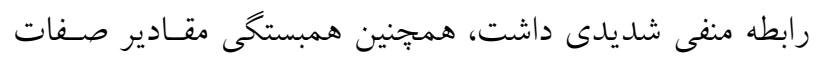

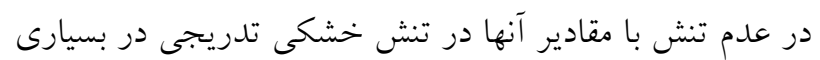
موارد كاهش جشمخيرى داشت.

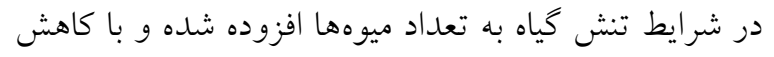
وزن هزار دانه باعث افزايش عملكرد ميوه شده اسـت. بنـابراين

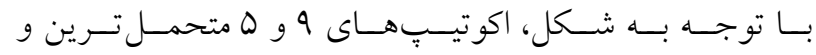
كمبازدهترين اكوتيٍها در شرايط بدون تنش بودند. با توجه بـهـ

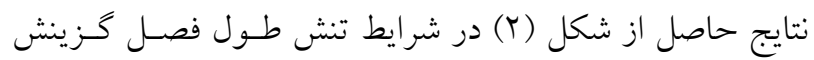

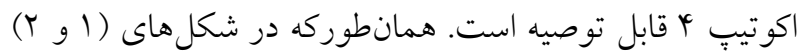

مشابهى بهدست آمده است. شاخص GMP در هـر دو آزمـايش

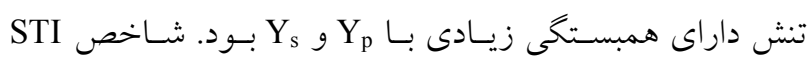

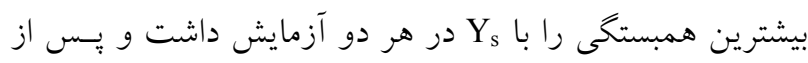

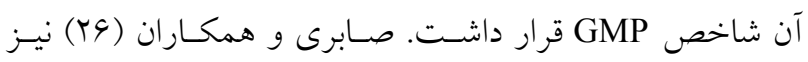
نتايج مشابهى را در مورد اين دو شاخص كزارش كردند. مقادير

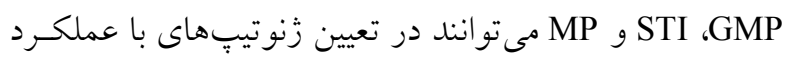

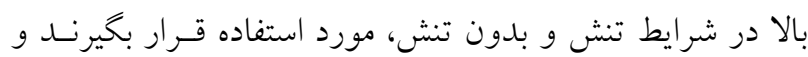

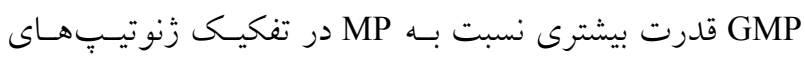
كروه A و حساسيت كمترى به مقــادير YP و YS دارد. بنـابراين

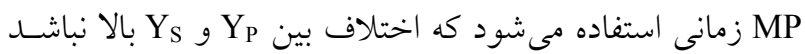

در تحقيقى شاخصهــاى مقاومـت بـه خشـكى در شـرايط مختلف محيطى مورد بررسى قرار كرفـت و مشـخص شــ كـهـ

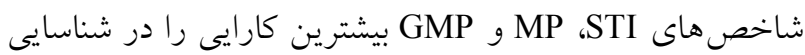

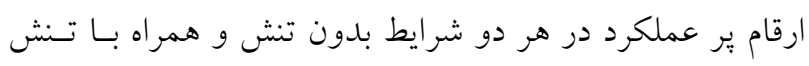

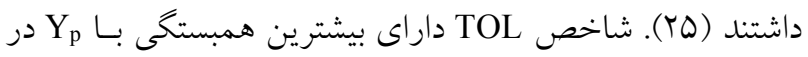

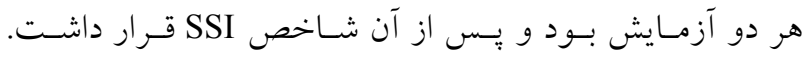

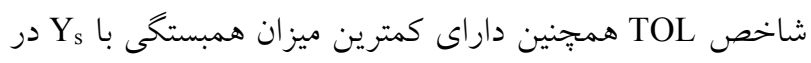

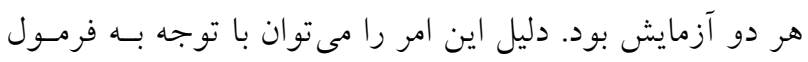

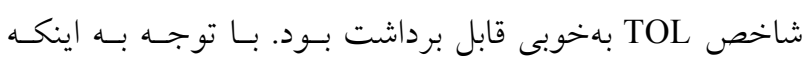

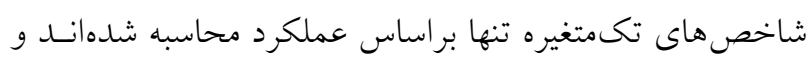

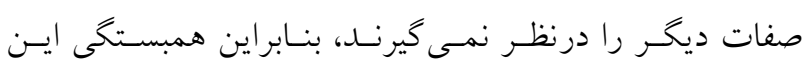

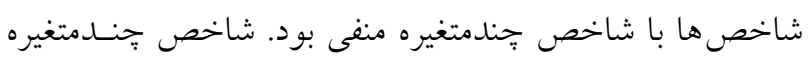

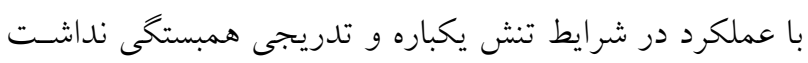

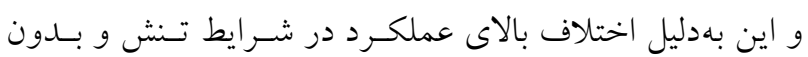

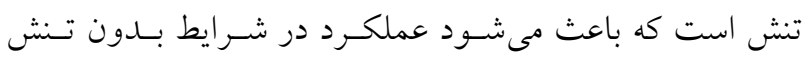

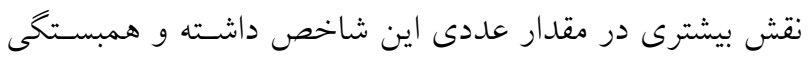
معنى دارى با آن داشته باشد.

باى يلات زنوتيب در صفت - محيط و شاخص جندمتغيره در

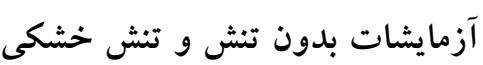

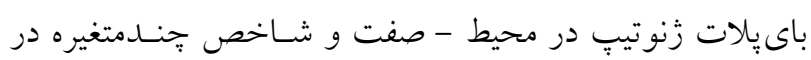




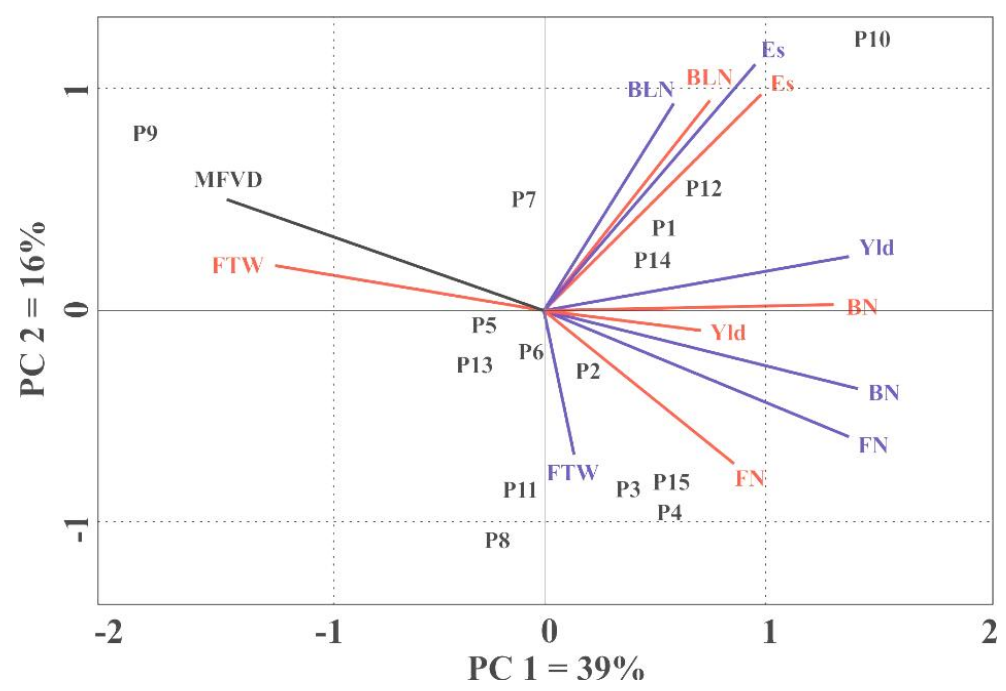

شكل ا. باى يلات زُنوتيٌ در محيط - صفت و شاخص جندمتغيره MFVD براى آزمايشات بدون تنش و تنش يكباره

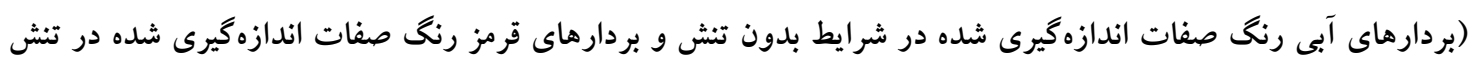

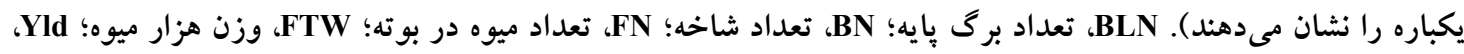

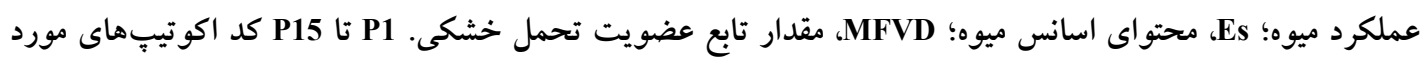
بررسى اشاره شده در (جدول () هستند (رنغى در نسخه الكترونيكى).

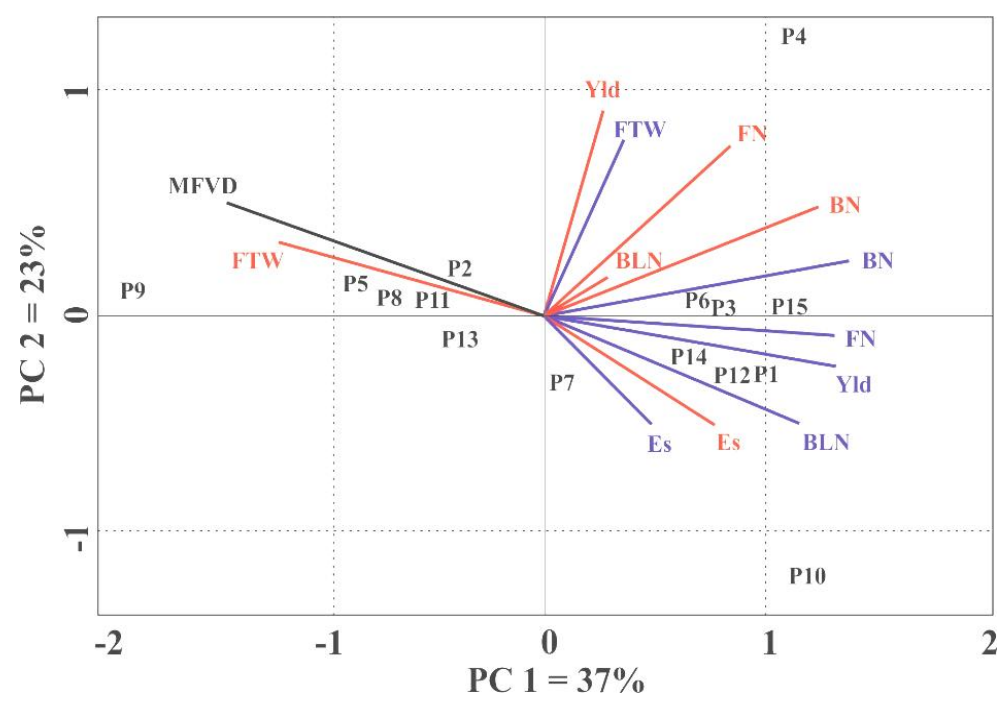

شكل r. باى بِلات زنوتيٌ در محيط - صفت و شاخص جندمتغيره MFVD براى آزمايشات بدون تنش و تنش تدريجى

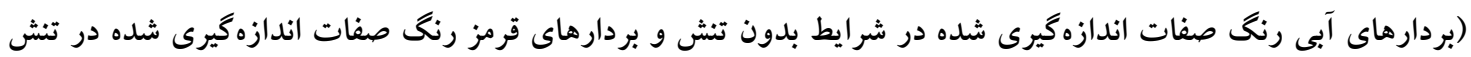

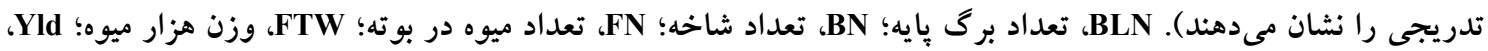
عملكرد ميوه؛ Es، محتواى اسانس. ميوه؛ MFVD، مقدار تابع عضويت تحمل خشكى P1 تا P15 كد اكوتيبهاى مورد بررسى اشاره شده در (جدول () هستند (رنغى در نسخه الكترونيكى). 


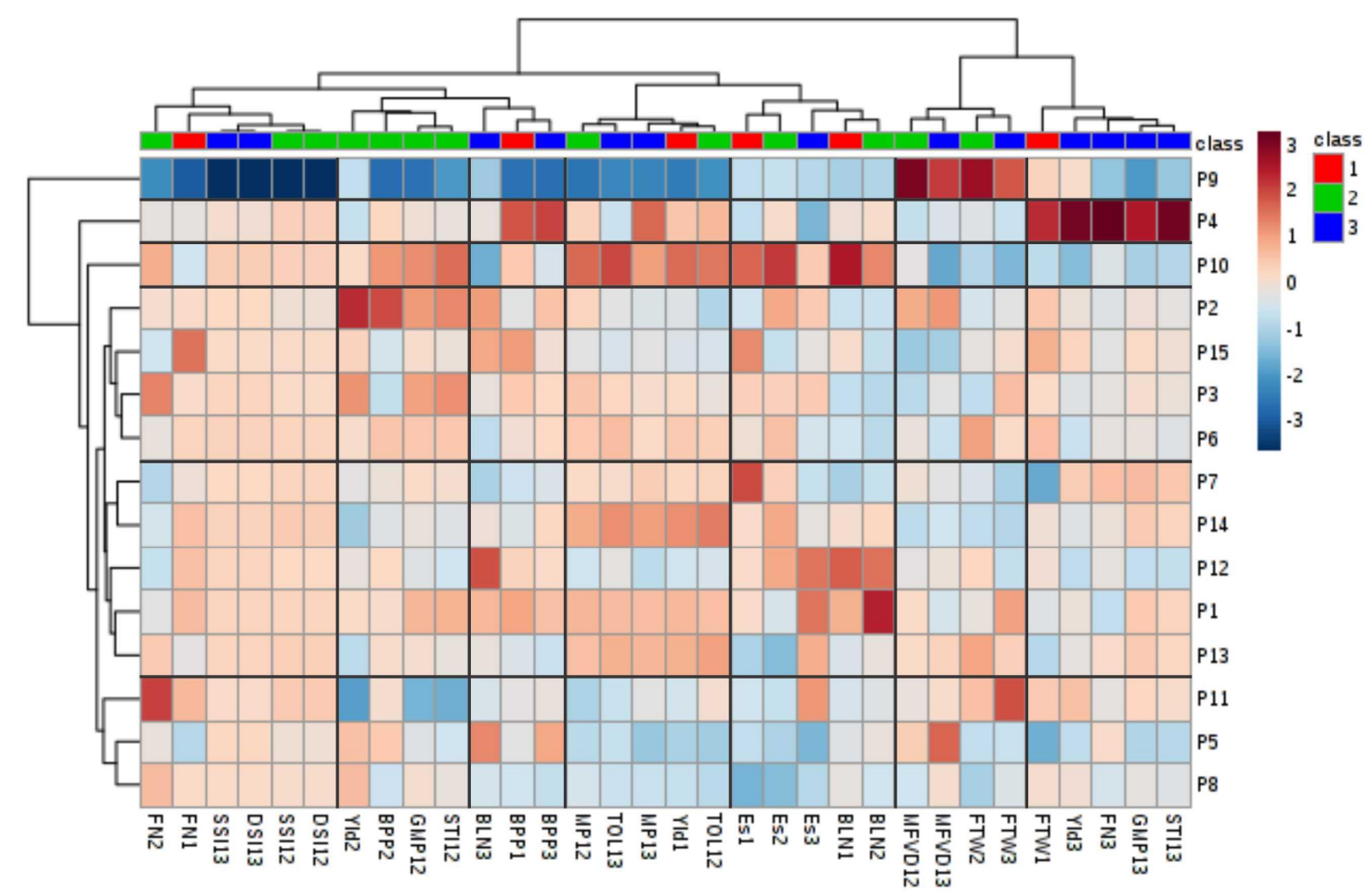

شكل r. هيتمب و گروهبندى اكوتيڤها و نمايش نحوه بروز صفات و شاخصها در محيطهاى مختلف BLN، تعداد برى بِايه؛ BN تعداد شاخه؛ FN، تعداد ميوه در بوته؛ FTW، وزن هزار ميوه؛ Yld، عملكرد ميوه؛ Es، محتواى اسانس ميوه؛ MFVD؛ مقدار تابع عضويت تحمل خشكى، SSI؛ شاخص حساسيت به تنش، DSI؛ شاخص حساسيت به خشكى، GMP؛ ميانگين هندسى بهرهورى، MP؛ ميانگين بهرهورى، TOL؛ شاخص تحمل، STI، شاخص تحمل تنش

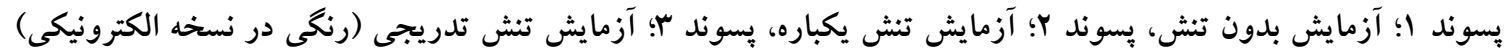

در يك گروه قرار گرفتند. اكوتيب ץ بـهدليـل عملكــد و اجـزاء

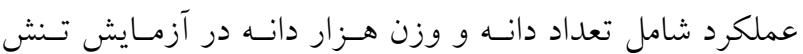
تدريجى، اكوتيبٍ 9 بهدليل بالا بودن وزن هزار ميـوه در شـرايط

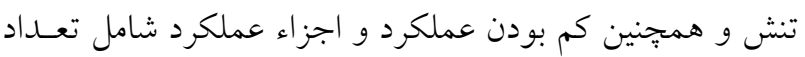
ميوه در بوته و تعداد شاخه در بوتسه در شـرايط بــدون تسنش و

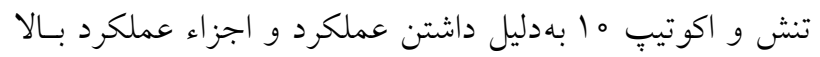
در شرايط بدون تنش و همين طور بـالا بـودن محتـواى اسـانس

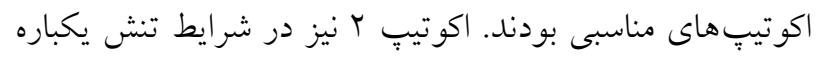

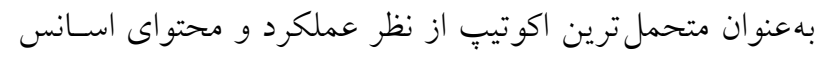

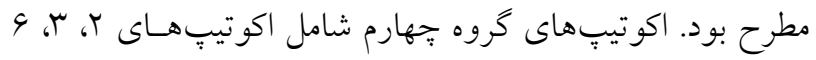

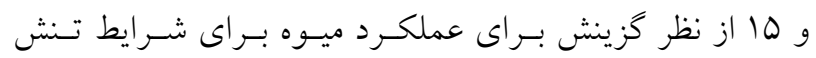

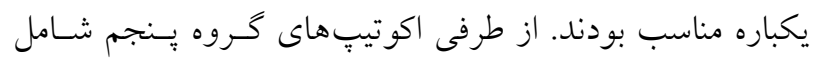

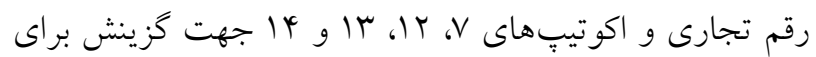

ملاحظه شد شـاخص MFVD قابليـت لازم را بـراى شناسـيى

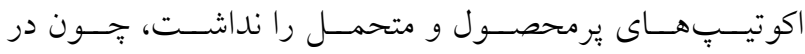
اكوتيِهاى مورد بررسى بــا افـزايش مقــار صـفات از تحمـل اكوتيبها كاسته شد.

هيتمب و گروهبندى اكوتيبها و نمايش نحوه بروز صسفات و شاخصها در محيطهاى مختلف

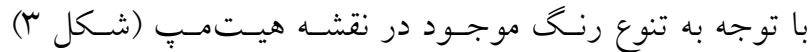

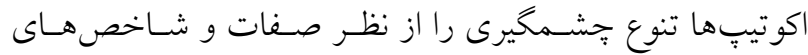
اندازهيرى شده در آزمايشهـاى بــدون تسنش، تسنش يكبـاره و تنش تدريجى از خود نشان دادند. در اين مطالعه اكوتيبهـا بـهـ

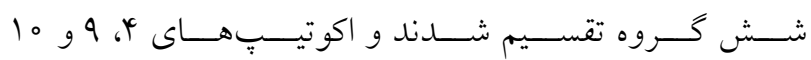

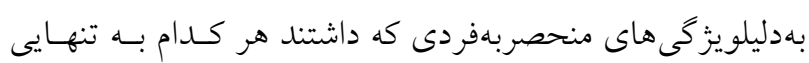


بركَهـا و در نتيجـه افـزايش توليــ فتوسـتزى باعـث افـزايش

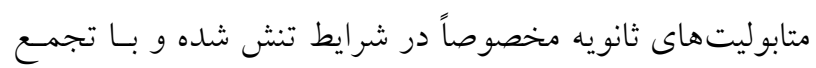

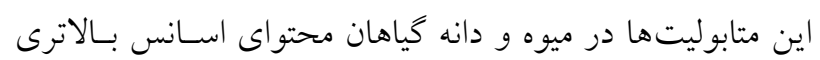

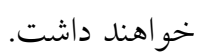

وجود همبستخى بين تعداد برك يايه و محتواى اسانس ميوه

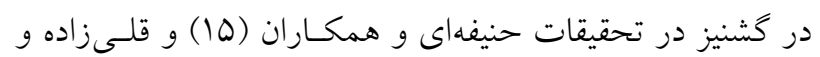

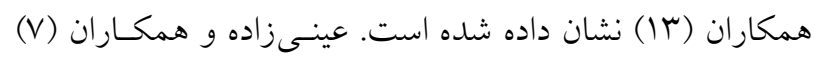

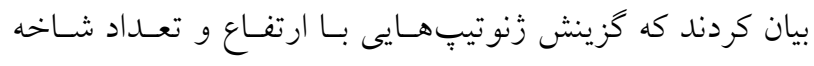

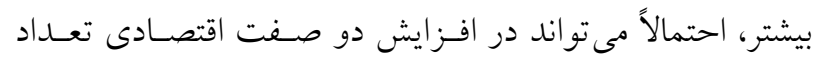

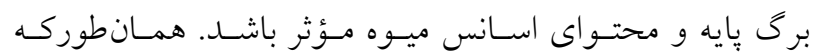

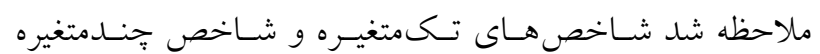

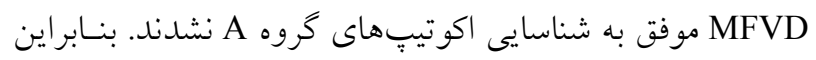

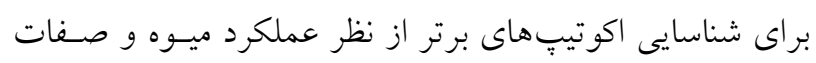

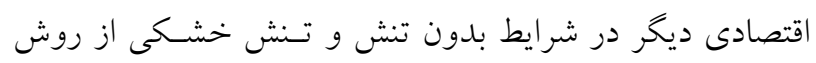
كرافيكى PCAMMI استفاده شد.

\section{كُووبندى اكوتيبها به روش PCAMMI}

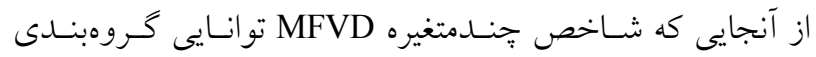

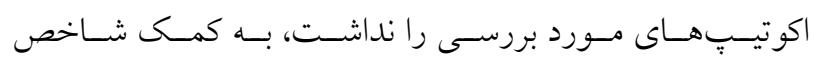

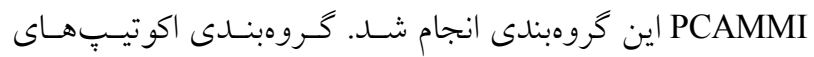

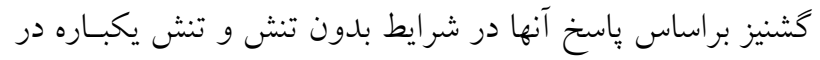

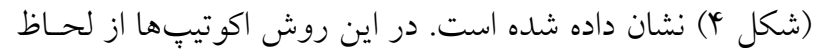

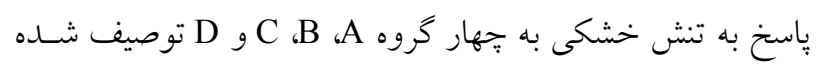

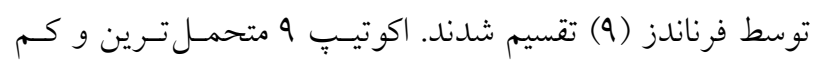

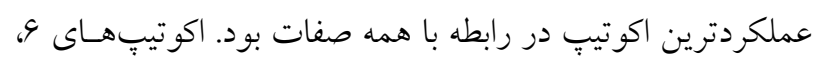

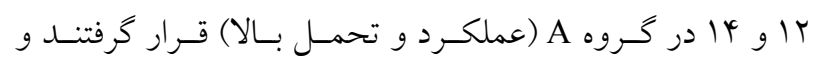

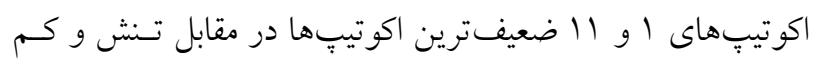

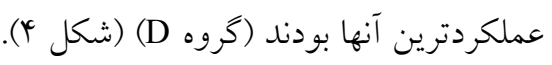

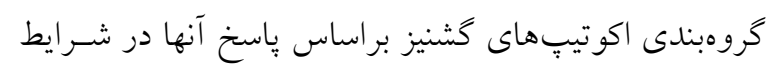
بلدون تنش و تنش تدريجى در (شكل ه) نشان داده شده اسـت.

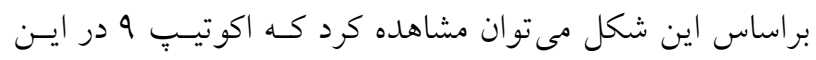

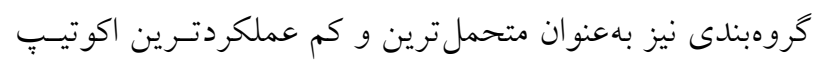

شرايط تنش تدريجى طول فصل مناسب بودند.

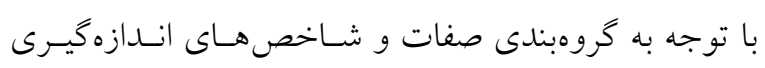

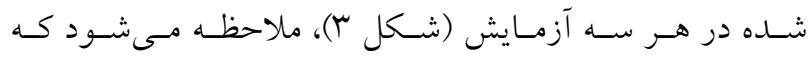
شاخص هاى تكمتغيره ارتباط بيشترى با عملكرد ميـوه داشـتند.

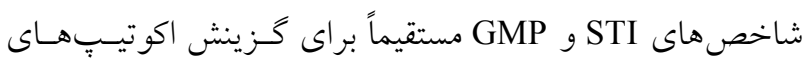

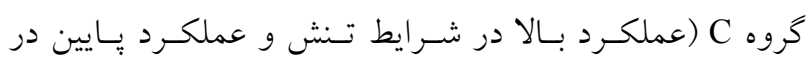
شرايط بدون تنش) مناسب بودند و ايسن موضـوع بـراى هـر دو

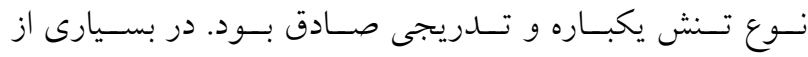

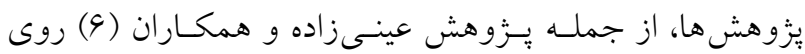
اكوتيبهاى كُشنيز، مشاهده شده است كه دو شـاخص GMP و STI رابطه نزديكى با يكديكر داشـته و بـهــور مرتـب از ايسن شاخص ها براى رسم نمودار سـهبعـدى فرنانــز اسـتفاده شـــه

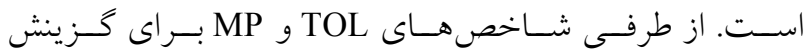

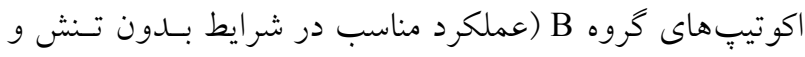

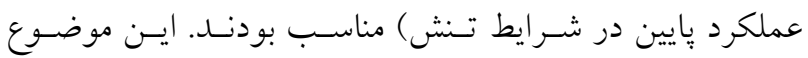

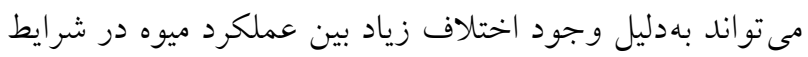
بدون تنش و تنش است كه در ايسن دو شـاخص باعـث ايجـاد

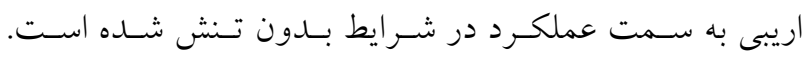

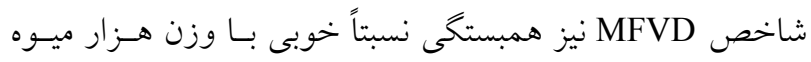
داشت (شكل r). با توجه به شكل (r) صفت تعداد شاخه در بوته با عملكـرد

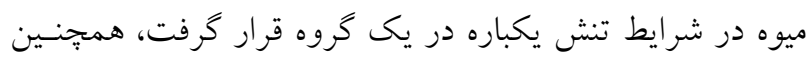

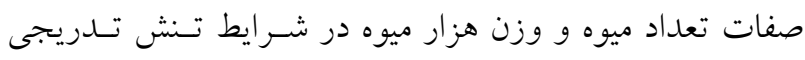

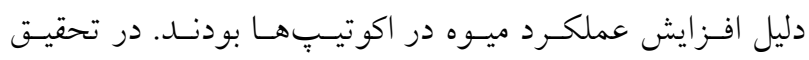

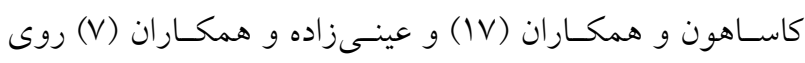

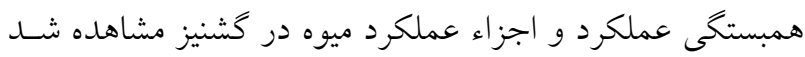

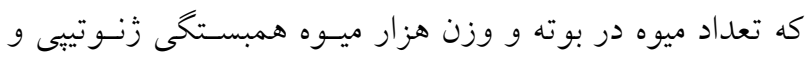
فنوتييى مثبت با عملكرد ميوه داشتند. همجنين در تحقيق هـانى

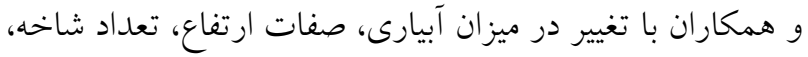

تعداد جتر و عملكرد بذر بهطور هماهنگ تغيير كردند (1)).

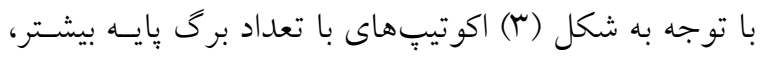

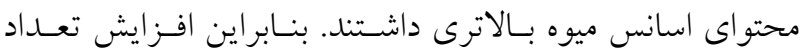




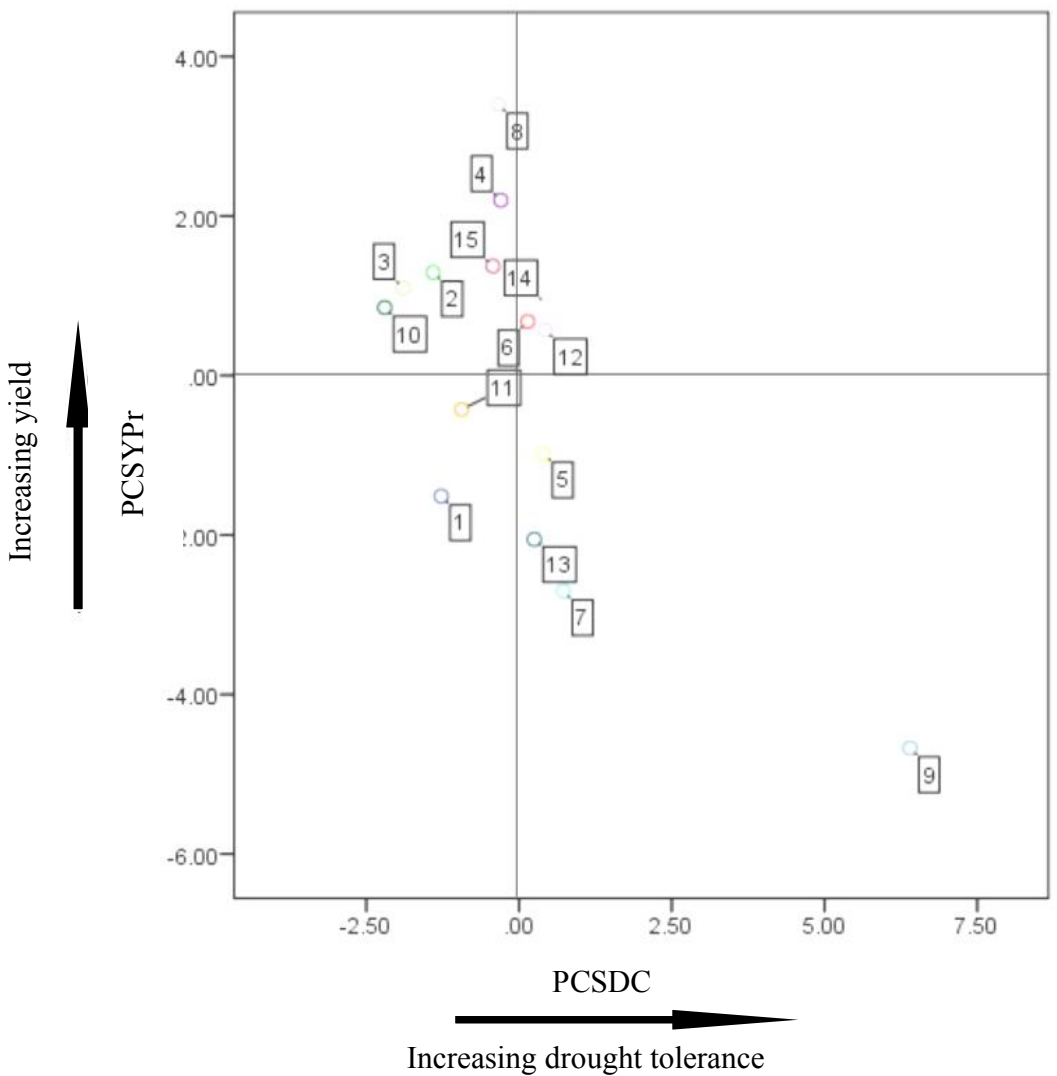

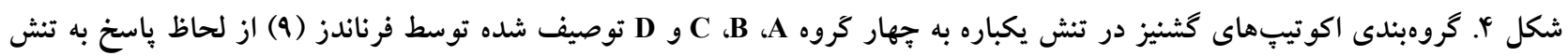
خشكى براساس شاخص PCAMMI با استفاده از كليه صفات؛ PCSDC و PCSYPr بهترتيب محورهاى ضرايب مؤلفهاى اصلى DC و YPr هستند.

شرايط تنش يكباره اكوتيبٍ هاى متحمل گيـاه كشـنيز بـه كمـى افزايش تعداد شاخهه و احتمـالاً افـزايش تعـداد جترهــاى بـارور نسبت به اكوتيبٍ هاى حساس، صدمات ناشى از تنش خشكى را بر روى عملكرد ميوه كم كردند و در شرايط تنش تدريجى ايسن امر از طريق افزايش تعـداد ميـوه و وزن هـزار ميـوه نسـبت بـهـ اكوتيِّهاى حساس صورت گرفت. محتـواى اسـانس ميسوه بـا افزايش تعداد برگهاى يايه افزايش يافـت. بنـابراين اسـتفاده از

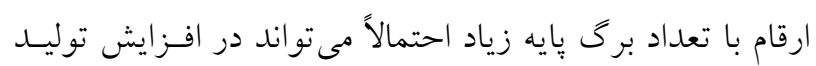
متابوليتها و در نتيجسـه افـزايش اسـانس ميـوه بـهـخصوص در

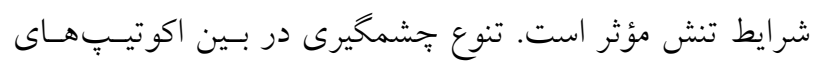
مورد بررسى وجود داشت و اكوتيِّها بـهـ شـش گـروه تقسـيم

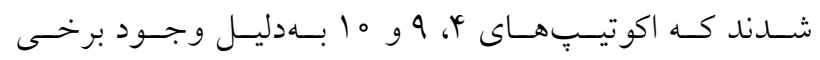
ويزّى هاى خاص هر كدام در يك گروه خـاص قـرار گرفتنـد.
در بين اكوتيِهاى مورد بررسى بود. در اين آزمايش اكوتيبٍهاى

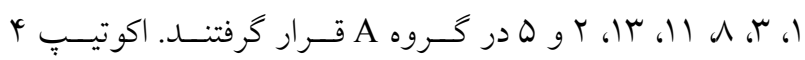

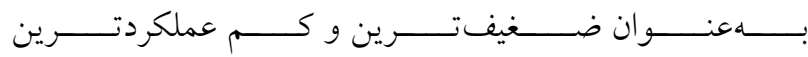
اكوتيبٍ (كروه D) در بين اكوتيڤهاى مورد بررسى شناسايى شد. رقم تجارى و اكوتيبٍ 11 حساسيت خيلى زيادى به تنش انتهـاى

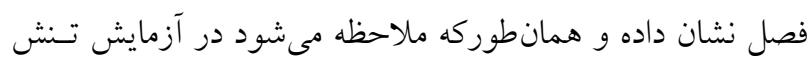

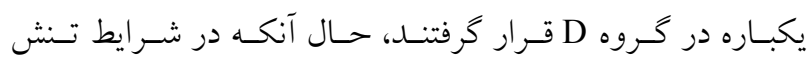
تدريجى در گـروه D قـرار داشـتند. بنـابراين اسـتفاده از ايسن دو

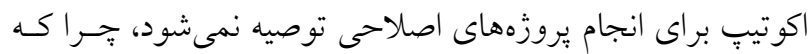

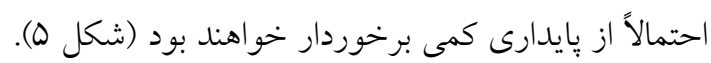

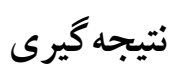

براساس نتايج بهدست آمده از اين بيزوهش مىتوان كفت كـه در 


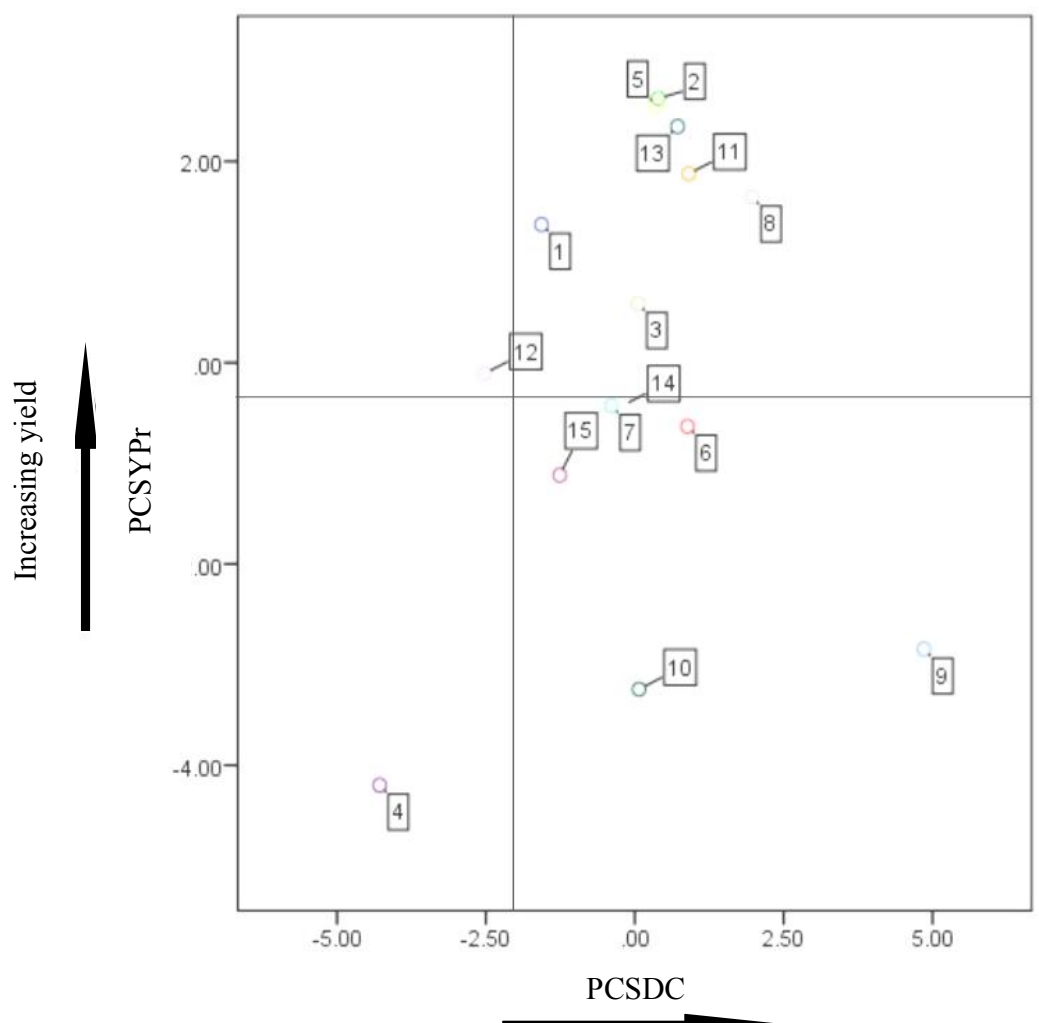

Increasing drought tolerance

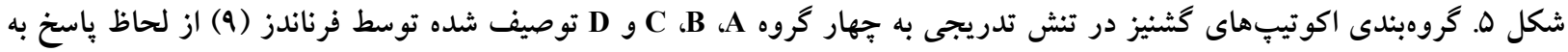
تنش خشكى براساس شاخص PCAMMI با استفاده از كليه صفات؛ PCSDC و PCSYPr بهترتيب محورهاى ضرايب مؤلفههاى اصلى DC و YPr هستند.

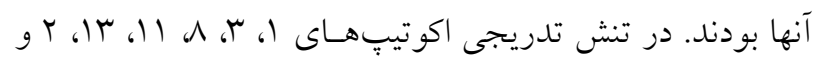

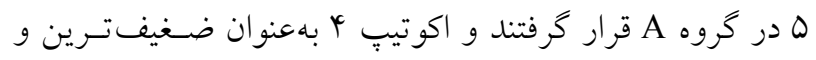

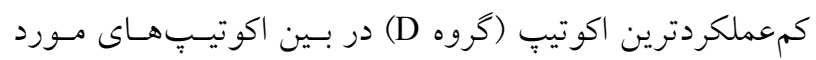

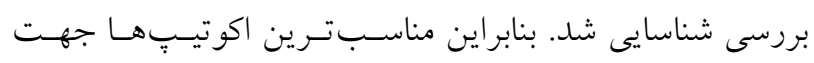
كزينش و تهيه جمعيت نسل بعد براى دستيابى به اكوتيسِهـاى

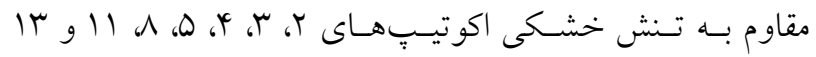
بودند. با توجه به اينكه تكامل هر اكوتيب بـا توجسه بـهـ شـر ايط

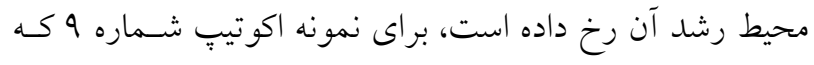

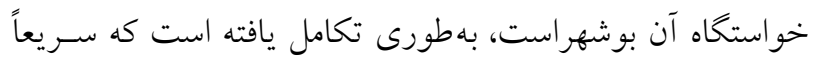

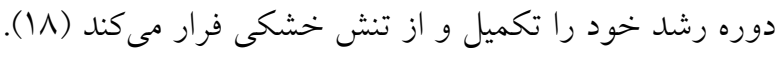

شــاخصهــاى تـــمتغيــره GMP و STI بـــراى شناسـيى اكوتيبٍ هاى گروه C و شاخص هاى MP و TOL براى شناسايى

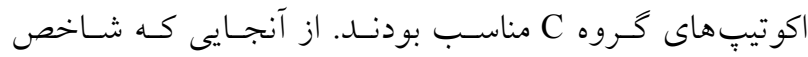

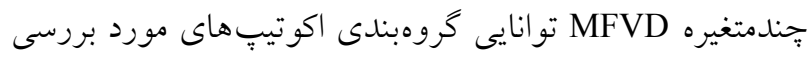
را نداشت، براى شناسايى اكوتيبهـاى گـروه A براسـاس كليـه

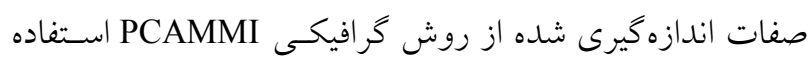
شد. براسـاس ايسن روش در هـر دو تسـش يكبـارهو و تـدريجى

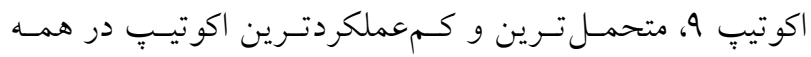

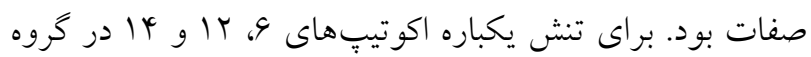

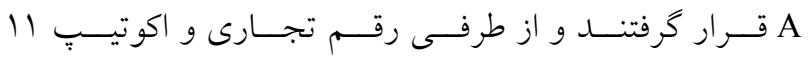

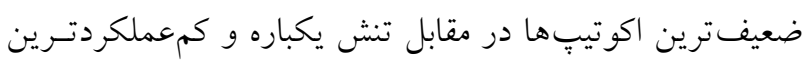


1. Blum, A. 1996. Crop responses to drought and the interpretation of adaptation. Plant Growth Regulation 20: $135-148$.

2. Chaghapur, Z., A. R. Zebarjadi and D. Kahrizi. 2014. Evaluation of drought tolerance of rapeseed (Brassica napus L.) genotypes in Laboratory and field conditions. Seed and Plant Improvement Journal 28: 17-38. (In Farsi).

3. Chen, X., D. Min, T. A. Yasir and Y. G. Hu. 2012. Evaluation of 14 morphological, yield-related and physiological traits as indicators of drought tolerance in Chinese winter bread wheat revealed by analysis of the membership function value of drought tolerance (MFVD). Field Crops Research 137: 195-201.

4. Diederichsen, A. 1996. Coriander (Coriandrum Sativum L.): International Plant Genetic Resources Institute. Bioversity International, Rome.

5. Dyulgerov, N. and B. Dyulgerova. 2013. Variation of yield components in coriander (Coriandrum sativum L.). Agricultural Science and Technology 5: 35-46.

6. Eynizadeh, P., H. Dehghani and M. Khodadadi. 2016. Drought stress Tolerance and Adaptation in Iranian endemic coriander (Coriandrum sativum L.) populations. Iranian Journal of Horticultural Science 47: 317-327. (In Farsi).

7. Eynizadeh, P., H. Dehghani and M. Khodadadi. 2017. Multipurpose selection of some Iranian endemic Coriander (Coriandrum sativum L.) populations for simultaneous improvement of traits in different irrigation regimes. Environmental Stresses in Crop Sciences. (Accepted In Farsi).

8. Fakheri, B. A., M. Jabari and M. Ziaee. 2012. Mapping of drought tolerance indices genomic locations in double haploid lines of Barley. Agronomy Journal (Pajouhesh and Sazandegi) 102: 118-123. (In Farsi).

9. Farshadfar, E. and P. Elyasi. 2012. Screening quantitative indicators of drought tolerance in bread wheat (Triticum aestivum L.) landraces. European Journal of Experimental Biology 2: 577-584.

10. Fernandez, G. C. J. 1992. Effective selection criteria for assessing plant stress tolerance. In: Proceedings of the International Symposium on Adaptation of Vegetables and other Food Crops in Temperature and Water Stress. pp. 257-270.

11. Fischer, R. A. and R. Maurer. 1978. Drought resistance in spring wheat cultivars. I. Grain yield responses. Crop and Pasture Science 29: 897-912.

12. Ghamarnia, H. and S. Daichin. 2013. Effect of different water stress regimes on different Coriander (Coriander sativum L.) Parameters in a semi-arid climate. International Journal of Agronomy and Plant Production 4: 822832.

13. Gholizadeh, A., H. Dehghani, M. Khodadadi. 2017. Estimation of genetic parameters, general and specific combining ability on endemic coriander populations. Journal of Plant Genetic Research (Accepted In Farsi).

14. 14- Hani, M., S. A. Hussein, M. Mursy, W. Ngezimana, F. N. Mudau. 2014. Yield and Essential Oil Response in Coriander to Water Stress and Phosphorus Fertilizer Application. Journal of Essential Oil Bearing Plants 18(1): 82-92.

15. Hanifei, M., H. Dehghani, M. Khodadadi. 2017. Estimation genetic parameters of some quantitative traits in coriander under drought stress using triple test cross. Journal of Plant Genetic Research 4(1): 25-38. (In Farsi).

16. Jansen, P. C. M. 1981. Spices, Condiments and Medicinal Plants in Ethiopia, their Taxonomy and Agricultural Significance. Backhuys, Ethiopia.

17. Kassahun, B. M., G. Alemaw, B. Tesfaye. 2013. Correlation studies and path coefficient analysis for seed yield and yield components in Ethiopian coriander accessions. African Crop Science Journal 21: 51-59.

18. Khodadadi, M., H. Dehghani and M. Jalali Javaran. 2017. Quantitative genetic analysis reveals potential to genetically improve fruit yield and drought resistance simultaneously in coriander. Frontiers in Plant Science 8: 1-16.

19. Khodadadi, M., H. Dehghani, M. Jalali Javaran and S. Rashidi-Monfared. 2014. Drought tolerance related traits in Coriandrum sativum L. and new multivariate statistical method for screening drought tolerant genotypes. In: Proceeding of the Phytotron Conference: In Analysis of Plants in Controlled Environments. Munich, Germany.

20. Kristin, A. S., R. R. Serna, F. I. Perez and B. C. Enriquez. 1997. Improving common bean performance under drought stress. Crop Science 37: 51-60.

21. Mardeh, A. S. S., A. Ahmadi, K. Poustini and V. Mohammadi. 2006. Evaluation of drought resistance indices under various environmental conditions. Field Crops Research 98: 222-229.

22. Mengesha, B., G. Alemaw and B. Tesfaye. 2011. Genetic divergence in Ethiopian coriander accessions and its implication in breeding of desired plant types. African Crop Science Journal 19: 24-35.

23. Minitab 16 Statistical Software. 2010. State College, PA: Minitab, Inc.

24. Montes, M., L. Muñoz and T. Wilkomirsky. 2001. Plantas Medicinales de uso en Chile. Química y farmacología,

25. Rosielle, A. A. and J. Hamblin. 1981. Theoretical aspects of selection for yield in stress and non-stress environment. Crop Science 21: 943-946.

26. Saberi, M. H., H. R. Nikkhah and H. Tajali. 2013. Effects of terminal drought stress on yield and choosing best tolerance indices in promising lines of Barley. Agronomy Journal 111: 27-34. (In Fsrsi). 
27. SPSS, I.B.M. 2011. IBM SPSS statistics base 20. Chicago, IL: SPSS Inc,

28. 228- Ward Jr, J. H., M. E. Hook. 1963. Application of a hierarchical grouping procedure to a problem of grouping profiles. Educational and Psychological Measurement 23: 69-81.

29. Xia, J., D. S.Wishart. 2016. Using metaboanalyst 3.0 for comprehensive metabolomics data analysis. Current Protocols in Bioinformatics 34: 10-14.

30. Zeinaly-Khanghah, H., A. Izanloo, A. H. Hoseinzadeh and N. Majnoonhoseini. 2004. Determination of the Suitable Drought Resistance Indices in Commercial Soybeans Varieties. Iranian Journal of Agricultural Science 35: 875885 (In Farsi). 


\title{
Selecting Drought Tolerant Endemic Coriander Ecotypes Based on Fruit Yield and Related Traits Using Univariate and Multivariate indices
}

\author{
P. Eynizadeh ${ }^{1}$, H. Dehghani ${ }^{*}$ and M. Khodadadi ${ }^{3}$
}

(Received: December 26-2017; Accepted: January 27-2018)

\begin{abstract}
Coriander is an annual plant belonging to Apiaceae family that its yield is affected by drought stress. Three experiments (normal irrigation regime, sudden drought stress and gradual drought stress) were conducted according to a randomized complete block design with three replications in 2015 to introduce the most drought tolerant Iranian coriander ecotypes based on several economical traits, aiming at improving them in next generations, using univariate and multivariate tolerance indices. The economic traits having high heritability and high correlation with the yield and fruit essential oil content were used to calculate multivariate index of the Membership Function Value for Drought Stress (MFVD) and multivariate graphical analysis based on Principal Component Mediated Multivariate Index (PCAMMI). Also, genotype by environment interaction was traced for normal and stress experiments. The ecotypes, traits and indices were categorized and their occurrence in the environments was showed using a Heatmap graphical mapping. Stable genotypes and suitable indices were identified. High variation was observed among ecotypes. Stress Tolerance Index and Geometric Mean Productivity indices were suitable for identification of genotypes belonging to group B, and Tolerance Index and Mean Productivity indices were suitable for identification of genotypes belonging to group C. The multivariate index of MFVD and thousand fruit weight was categorized into the same group. Therefore, this index was not effective for separating ecotypes. Ecotypes were grouped using the PCAMMI graphical technique. In sudden drought stress, ecotypes 6, 12 and 14, and in gradual drought stress, ecotypes 1, 2, 3, 5, 8, 11 and 13 were grouped in group A.
\end{abstract}

Keywords: Biplot, Drought stress adaptation, Heatmap graphical mapping, Multivariate index, Tolerance index

1, 2, 3. PhD. Student, Professor and PhD. Graduated Student, Respectively, Department of Plant Genetics and Breeding, Faculty of Agriculture, Tarbiat Modares University, Tehran, Iran.

*: Corresponding Author, Email: dehghanr@modares.ac.ir 